Article

\title{
How Can Deep Geothermal Projects Provide Information on the Temperature Distribution in the Upper Rhine Graben? The Example of the Soultz-Sous-Forêts-Enhanced Geothermal System
}

\author{
Béatrice A. Ledésert* ${ }^{\mathbb{D}}$ and Ronan L. Hébert ${ }^{(D)}$ \\ Geosciences and Environment Cergy (GEC), CY Cergy Paris University, F-95000 Cergy, France; \\ ronan.hebert@cyu.fr \\ * Correspondence: Beatrice.ledesert@cyu.fr; Tel.: +33-1-34-25-73-57
}

Received: 12 October 2020; Accepted: 9 November 2020; Published: 13 November 2020

\begin{abstract}
The Upper Rhine Graben (URG) hosts thermal anomalies that account for the development of oil fields. Recently, a geothermal power plant has been installed in this area. Data obtained in this framework provide an insight into the temperature distribution in the URG. The present thermal gradient at Soultz-sous-Forêts is not linear: nearly $90{ }^{\circ} \mathrm{C} / \mathrm{km}$ down to $1400 \mathrm{~m}$ depth, then about $12^{\circ} \mathrm{C} / \mathrm{km}$ from that depth down to $5000 \mathrm{~m}$. The combination of temperature conditions and natural fluid circulation in fracture networks has led to the hydrothermal alteration of the granite into mineral assemblages such as those including illite, quartz and calcite. Illite is locally impregnated with organic matter of two kinds: a mature type derived from oil source rocks and a less mature type derived from surficial sedimentary layers indicating the km-scale of transfer. Newly formed crystals of quartz and calcite from around $2000 \mathrm{~m}$ depth record a fluid temperature range of 130 to $170{ }^{\circ} \mathrm{C}$, consistent with modelling and the temperatures measured at present in the drill-holes at this depth. In such hydrothermally altered zones, local variations of temperature are encountered indicating current fluid flows that are being sought for geothermal purposes.
\end{abstract}

Keywords: Upper Rhine Graben; Soultz-sous-Forêts; Rittershoffen; thermal gradient; temperature measurement; geothermal power plant; newly formed minerals; fluid-inclusion microthermometry

\section{Introduction}

To be economically sustainable, high-temperature $\left(150-200^{\circ} \mathrm{C}\right)$ geothermal projects need to be developed in areas where the thermal gradient is high enough to avoid drilling very deep boreholes which are extremely expensive. To this end, we need to take a careful look at the geological context (see for example [1]). Enhanced geothermal systems (EGS; [2]) developed in such environments also require stimulations of the boreholes and surrounding rocks to ensure a sufficiently high yield to allow electricity production. As a prior step, it is necessary to obtain a good knowledge of the rock mass (nature, discontinuities, newly-formed minerals) within which the EGS is to be installed to precisely locate the zones needing stimulation. The present paper focuses on the Upper Rhine Graben (URG) and one of its emblematic sites: the Soultz-sous-Forêts EGS, called Soultz in the following.

\subsection{Present-Day Thermal Anomalies}

It has long been known that the URG hosts thermal anomalies [3,4]. The fracture network cited above has been thoroughly analysed and modelled at Soultz by many authors [5-8], and also at Rittershoffen $[9,10]$. In the basement, these fractures yield a hot brine at $160^{\circ} \mathrm{C}$ extracted for geothermal 
purposes, which is used for electricity generation at Soultz and thermal energy at Rittershoffen $10 \mathrm{~km}$ apart (Figures 1 and 2).

From thermodynamic calculations, [11] indicate that the fluid currently sampled from granite in the EPS-1 borehole at Soultz attained a peak temperature of around $200^{\circ} \mathrm{C}$ while it was within Permo-Triassic sandstones. According to more recent studies [12], chemical, isotopic and gas geothermometers applied at different sites in the URG indicate concordant reservoir temperatures close to $225 \pm 25^{\circ} \mathrm{C}$ for all the fluids, even though the maximum temperature so far measured on site is $200{ }^{\circ} \mathrm{C}$, at about $5000 \mathrm{~m}$ depth at the bottom of the Soultz drill holes (Figure 1). Accordingly, this latter study suggests a deep Triassic sedimentary origin ( $\geq 4 \mathrm{~km}$, centre of the URG) for the geothermal fluids collected in the granite. The presence of several distinct geothermal reservoirs at the URG scale is highlighted by the variable values of total dissolved salts and $\mathrm{Cl} / \mathrm{Br}$ ratios. The chemical and isotopic compositions of hot brines collected at Soultz and Rittershoffen can be compared with cooler brines from Brühl and the Landau Eocene-Oligocene oilfield wells. This reveals many discrepancies due to high-temperature water-rock interactions. The hottest brines are depleted mainly in $\mathrm{Mg}, \mathrm{SO}_{4}$ and $\mathrm{B}$ and have much lighter $\mathrm{Li}$ and $\mathrm{B}$ isotope signatures. They are also highly enriched in $\mathrm{K}, \mathrm{Ca}, \mathrm{SiO}_{2}, \mathrm{Li}, \mathrm{Rb}, \mathrm{Cs}, \mathrm{As}, \mathrm{Sr}, \mathrm{Ba}, \mathrm{Mn}, \mathrm{Nd}$ and $\mathrm{U}$ as well as heavy metals $(\mathrm{Zn}, \mathrm{Pb}, \mathrm{Cu}, \mathrm{Co}, \mathrm{Cd}$ and $\mathrm{Sb})$. The He isotopic signature of the gases associated with the brines at Insheim and Bruchsal confirms that the thermal anomalies are mainly crustal and not mantle-derived [12]. Thus, it is concluded that the thermal anomalies are associated mainly with the convective circulation of hot fluids along probable NE-SW faults between the deep sedimentary centre of the graben and the fractured granite basement at its edges (Figure 1). Moreover, the western part of the Upper Rhine Graben (the Landau, Insheim, Soultz, Rittershoffen and Cronenbourg sites) seems to be hotter than the eastern part (Bruchsal and Bühl) (Figure 2). The Buntsandstein brine collected from the 2870-m-deep Cronenbourg geothermal well [13-15] has similar chemical and isotopic characteristics; its temperature at depth, estimated using chemical and isotope geothermometry, is also comparable to the fluids present in the granite basement $\left(225 \pm 25^{\circ} \mathrm{C}\right)$. According to the U-Th isotope system, the minimum transit time of these deep geothermal brines would be about 1000 years [12].

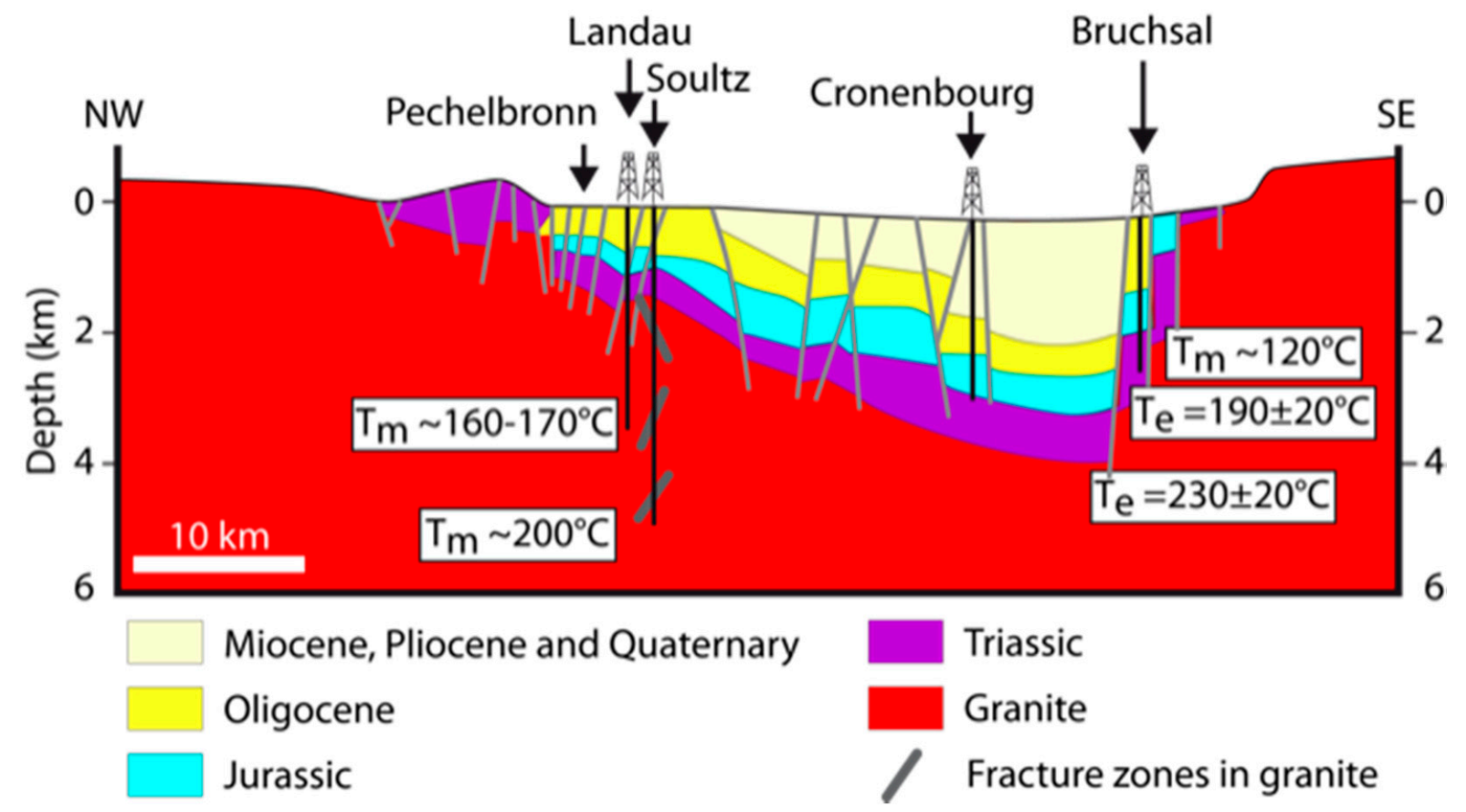

Figure 1. Cross-section of the Upper Rhine Graben (URG) modified after [12]. The temperatures were measured in drillholes (Tmeas.) or estimated from geothermometers (T est.), with their values indicated at the depth at which they were measured or estimated. 
The map in Figure 2 shows that a major thermal anomaly is centred on Soultz, which explains why a European geothermal programme was set up there in the 1980s [16].

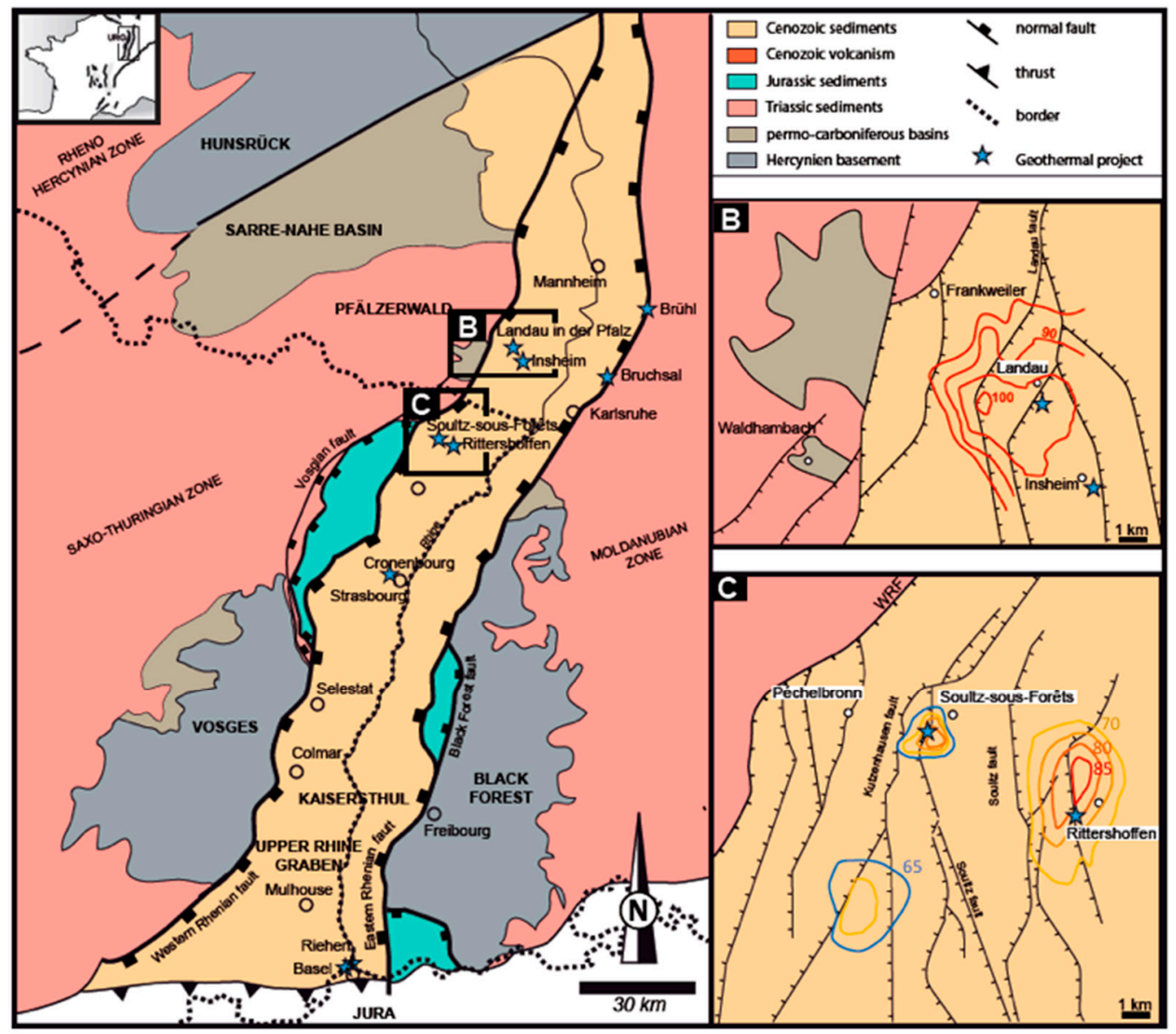

Figure 2. Map of thermal anomalies. Location and simplified geology of the Upper Rhine Graben. Coloured lines indicate isotherms ranging from $50{ }^{\circ} \mathrm{C}$ (blue line) to $130{ }^{\circ} \mathrm{C}$ (red line) at $1500 \mathrm{~m}$ depth. Modified after [17].

On a wider scale, [18] provides another map with geothermal gradients in Germany, including the URG, based on temperatures measured in 10,559 wells, including 1098 wells in which the temperature was measured at depths greater than $3000 \mathrm{~m}$. Together with more than 700 ground-level data points, these authors developed a three-dimensional estimate of the subsurface temperature distribution in Germany.

The URG is clearly identified on these maps, in particular on a map showing the spatial variation of the geothermal gradient in Germany [18]; the highest gradient in Germany appears to be located in the URG, where it reaches $100{ }^{\circ} \mathrm{C} / \mathrm{km}$. This value is close to that measured at Soultz where the gradient reaches $110{ }^{\circ} \mathrm{C} / \mathrm{km}$ in the sedimentary basin around the EGS site [16]. However, in the Soultz granitic basement, the thermal gradient is normal, with a value of $28^{\circ} \mathrm{C} / \mathrm{km}$ [12]. On the whole, [19] observed thermal gradients in the range of $40-60^{\circ} \mathrm{C} / \mathrm{km}$ at the graben centre. Values can be much higher on its western border, as shown by [10] at Rittershoffen (Figure 3), where a gradient of slightly more than $90{ }^{\circ} \mathrm{C} / \mathrm{km}$ is encountered, and even more around Soultz, probably because the site is located on a horst $[20,21]$.

The temperatures measured at present in geothermal wells are given in Table 1 . Very low gradients are found in the granite at Soultz and Rittershoffen (22.2 and $15.7^{\circ} \mathrm{C} / \mathrm{km}$ respectively) compared to values in the sedimentary cover $\left(85.7\right.$ and $83.1^{\circ} \mathrm{C} / \mathrm{km}$ respectively), indicating differences in the thermal regime between these two media. 


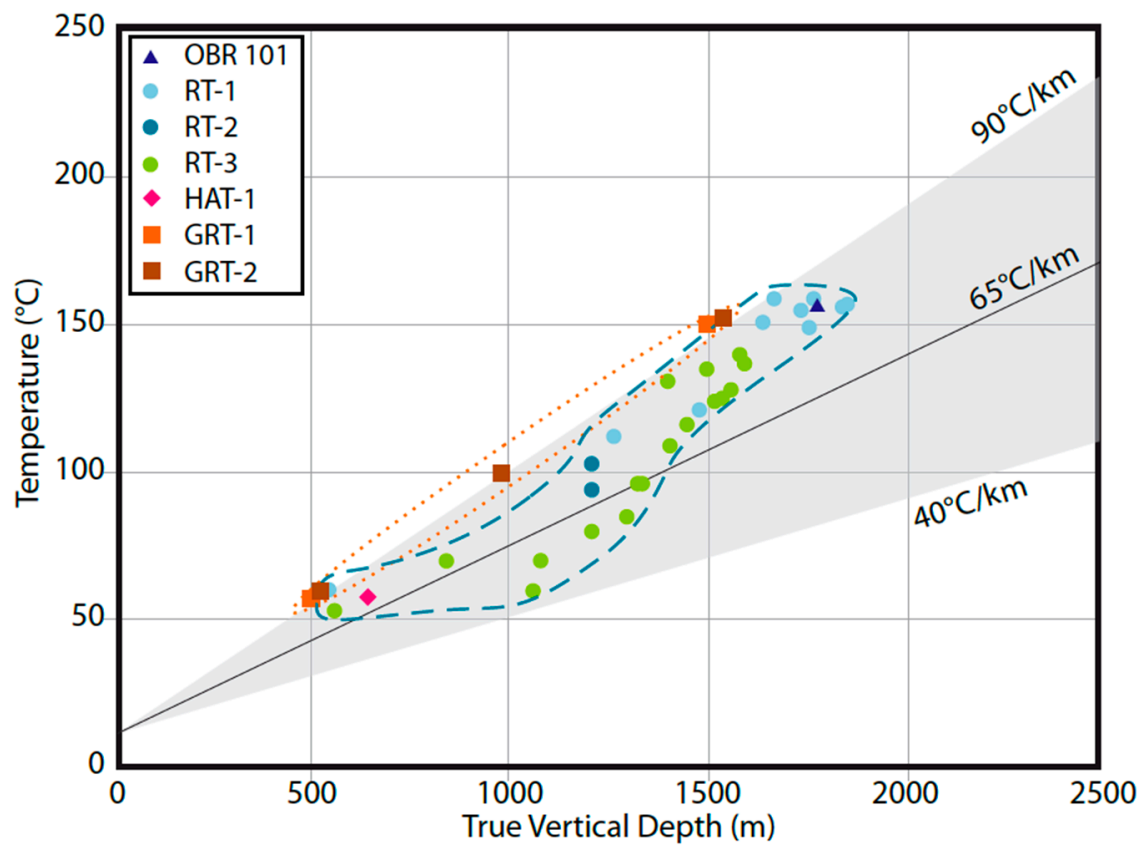

Figure 3. Thermal gradients in the sedimentary cover of the URG (modified after [10]). Data from Rittershoffen geothermal wells (GRT-1 and GRT-2) and from oil wells (OBR, RT, HAT).

Table 1. Temperatures measured in the drillholes of five geothermal sites in France (Soultz and Rittershoffen), Germany (Landau and Insheim) and Switzerland (Basel), after [12,17]. For location map, see Figure 2.

\begin{tabular}{ccc}
\hline \multirow{2}{*}{ Geothermal Site } & Temperature in ${ }^{\circ} \mathbf{C}$ & Temperature in ${ }^{\circ} \mathbf{C}$ \\
\cline { 2 - 3 } & (Base of Triassic) & (Bottom Hole in Granite) \\
\hline Soultz & $120(1400 \mathrm{~m})$ & $200(\mathrm{ca} 5000 \mathrm{~m})$ \\
Rittershoffen & $160(1925 \mathrm{~m})$ & $180(3200 \mathrm{~m})$ \\
Landau & & $160-170(\mathrm{ca} 3200 \mathrm{~m})$ \\
Insheim & & $165(3620 \mathrm{~m})$ \\
Basel & & $190(5000 \mathrm{~m})$ \\
\hline
\end{tabular}

More details about these boreholes (year of drilling, top of open hole and its lithology, hydraulic yield, stimulation, $\mathrm{pH}, \mathrm{TDS}$ ) can be found in [17].

In addition, [22] worked on the conductive and convective heat transfer in the sedimentary basin of URG, in the Miocene and Oligocene sediments. These authors used three independent data sets: (1) Energy budget considerations based on hydraulically perturbed thermal data (shallow boreholes, $<500 \mathrm{~m}$ ); (2) 1-D vertical Peclet number (Pe) analysis of thermal data (22 deep boreholes, > $1000 \mathrm{~m}$ ); and (3) 2-D finite difference modelling of the fully coupled fluid flow and heat transport equations on a vertical cross-section of the entire Rhine graben. Their modelling gives values in the range $80 \pm 10 \mathrm{~mW} . \mathrm{m}^{-2}$ for average conductive basal heat flow density entering the graben from below, at the interface between the crystalline basement and the sedimentary basin. They also demonstrated that the thermal anomalies along the western border of the graben (e.g., Pechelbronn or Landau, see Figure 2 for location) can be explained by a basin-wide, deep rooted E-W groundwater circulation that locally enhances the background basal heat flow density by $50 \%$ at the global scale, and by as much as $120 \%$ at individual sites. For example, in the area of the Western Rhenian fault located to the west of the graben [17], there is a regional anomaly of the order of $120 \mathrm{~mW} \cdot \mathrm{m}^{-2}$, with peak values of up to $140 \mathrm{~mW} \cdot \mathrm{m}^{-2}$ [22]. The Western Rhenian fault acts as a discharge zone for the basin-wide circulation system, where the average background value is enhanced by an additional convective component [22]. 
Indeed, we can use the Peclet number to characterise a hydrothermal system with respect to the dominant physical transport process. The system is conductively dominated if $\mathrm{Pe}<1$, while it is convectively dominated if $\mathrm{Pe}>1$. According to [22], there is strong evidence that the geothermal anomalies in the western part of the central URG (for example at Pechelbronn or Landau) are due to a graben-wide fluid circulation on top of a slightly elevated average regional basal heat flow density of $80 \pm 10 \mathrm{~mW} \cdot \mathrm{m}^{-2}$. Hence, a strong correlation exists between local thermal anomalies and fluid flow, which is a key point for geothermal operation.

Based on modelling, [23] studied the influence of the main border faults on the 3D hydraulic field of the central URG. For this purpose, they carried out a sensitivity analysis on fault width and permeability. Since fluid velocity and temperature depend on the width and permeability of the main border faults, these parameters are used only in direct proximity of the modelled faults. Therefore, the hydraulic characteristics of these faults do not significantly influence the graben-scale groundwater flows. The main findings of [23] are as follows: (1) A topography-driven basin-wide fluid flow perpendicular to the rift axis from the graben shoulders to the rift centre; (2) a N/NE-directed flow parallel to the rift axis in the centre of the rift and; (3) a pronounced upflow of hot fluids along the rift central axis, due to merging of streams from both sides of the rift.

\subsection{Organic Matter Maturity as an Evidence of Thermal History}

It is well-known that the maturity of organic matter provides valuable information about temperature in sedimentary basins. In the following, organic matter is used to get data on the thermal history of the basin and thus better understand the present-day temperature distribution in the Upper Rhine Graben (URG). The URG is the oldest known oil province in Western Europe, where the exploitation of tar sands at Pechelbronn, only $5 \mathrm{~km}$ west of Soultz, started on a small scale in 1498. This locality takes its name from the Alsatian dialect word for tar (Pechel) spring (Bronn). At Pechelbronn, more than 5500 wells were drilled up until $1964[3,4]$.

In Germany, [24,25] provide information about thermal maturity and petroleum kitchen areas in the Liassic Black Shales (Lower Jurassic) of the central URG. These authors based their work on vitrinite reflectance measurements, Rock-Eval pyrolysis $\left(\mathrm{T}_{\max }\right)$ and the spore coloration index. At depths $<600 \mathrm{~m}$ (outcrops and shallow wells), the Liassic Black Shales reach maturities indicating a very early to early oil window (ca. $0.50-0.60 \%$ vitrinite reflectance, VRr). This global low maturity pattern implies that there was only minor oil generation and expulsion from the Liassic Posidonia black shales prior to the formation of the URG [24]. The Posidonia Shale reached maximum temperatures of about $80-90{ }^{\circ} \mathrm{C}$ before graben formation, likely during Late Cretaceous times. These consistent data over a large area imply a relatively uniform burial- and temperature-related maturity maximum. The maximum Mesozoic temperatures were possibly influenced by higher heat flows at the onset of the rifting event, at about $70 \mathrm{Ma}$ [24]. These authors observed very high VRr gradients (ca. 1.5\% VRr) in deep areas of the URG, showing that the highest maturity levels correspond to the wet gas window. This central zone hosts significant kitchen areas in the Posidonia Shale. In these deep areas, the maximum temperatures during upper Oligocene to Miocene times greatly exceeded those attained during the Cretaceous [22]. The complex tectonic history of the URG includes periods of subsidence and uplift, which have led to its present-day structure. These events are expected to have had a key influence on the geographic distribution of source rocks and their maturation history, as well as the migration pathways and trapping of hydrocarbons $[25,26]$.

This paper summarises the data obtained by the present authors, merging it with literature data to give an overview of temperature distribution in the URG. We aim to show how contributions from petrography and petrophysics can help in deciphering the temperature distribution in the URG, illustrating the importance of this approach for geothermal exploration and further production of electricity and heat. Particular emphasis is placed on the emblematic Soultz geothermal site. 


\section{Geological Setting}

The URG is a NNE-SSW striking continental rift (Figure 1) approximately $300 \mathrm{~km}$ in length forming the central section of the European Cenozoic Rift System [27]. During Triassic times, the Buntsandstein (pink sandstone), Muschelkalk (clayey limestone) and Keuper (evaporites) formations were deposited [27]. Clayey to marly Liassic sediments were deposited on a subtropical shelf [28]. Then, the northern URG underwent a gradual uplift in end-Jurassic to Early Cretaceous times [29] that led to a lower thickness of Upper Jurassic sediments and significant erosion in the late Cretaceous [24]. Thus, Cretaceous sediments are not encountered in the URG. The formation of the graben started during the Eocene in response to the build-up of northward-directed intraplate stresses related to the collision in the foreland of the Alps and the Pyrenees [30,31]. The main rifting period occurred during the Oligocene, with a graben filling more than $4000 \mathrm{~m}$ thick [6]. A transtensive sinistral shear movement started at about 25 Ma during the Miocene, after the main rifting period. At the same time, the southern part of the URG was uplifted and upper Oligocene sediments were eroded $[29,32]$. Opening of the graben and subsequent sinistral shear movements were superimposed onto the Variscan structure of the crystalline basement. This basement is composed of three major tectonic terranes intruded by Carboniferous granitoids of Visean (340 Ma) and Permian (270 Ma) age [27]. These granitoids crop out on the western (Vosges and Hardt) and eastern (Black Forest) shoulders of the URG and are found at depth in the graben, in particular at Soultz (Figure 1). Because of the tectonic history of this area, the crystalline basement and its sedimentary cover are crosscut by a great number of steeply dipping faults and fractures (Figure 1).

\section{Material and Methods}

\subsection{Material}

At Soultz, the EGS consists of five boreholes. Among these, GPK-2, GPK-3 and GPK-4 make up the European geothermal pilot plant, which extends to more than $5000 \mathrm{~m}$ depth. GPK-2 is the production well (brine produced at $160^{\circ} \mathrm{C}$ ) while GPK-3 and GPK-4 are currently used for reinjection $\left(\right.$ at $70{ }^{\circ} \mathrm{C}$ ). The water produced from the pilot plant is reinjected to avoid depletion of the aquifer. This is also done for environmental reasons, to avoid contamination of surface waters by deep groundwaters. GPK-1 is a 3600 m-deep exploration well dedicated to the first hydraulic tests. EPS-1 was fully cored down to $2230 \mathrm{~m}$ for exploration and scientific purposes. Some wells for seismic observation are located near the geothermal plant, including the 1400-m deep well referred to as well 4550 which is the closest to the wellhead of GPK1 [8].

The Soultz deep drillholes were either partly cored (GPK-1 and GPK-2) or drilled under destructive conditions (GPK-3 and GPK-4). Cutting samples represent crushed rocks obtained during destructive drilling operations. Rock fragments range in size from less than $1 \mathrm{~mm}$ to several $\mathrm{mm}$. During drilling operations, cuttings are possibly mixed with neighbouring levels in the drilling mud and thus represent an average composition for a certain interval of about $3 \mathrm{~m}$ thick [33]. Thus, it is only possible to detect petrographic variations affecting zones more than $3 \mathrm{~m}$ thick. Cuttings from GPK-1, GPK-2, GPK-3 and GPK-4 were collected at intervals of 3 to $6 \mathrm{~m}$. Sampling rate depends on the Rate of Penetration (ROP) recorded during drilling operations. At Soultz, high ROP values correlate with fracture zones where natural brine was sometimes identified during injection tests [34], whereas low ROP values are related with unaltered rock masses [34]. All the Soultz wells were logged on-site by the same geological team using the same methodology [35-38] based on the results from the exploration of fully cored well EPS-1 [5]. Thus, this methodology allows direct comparisons between wells. Cuttings were washed to remove drilling mud before analysis. They were logged in detail on site by conventional binocular microscope examination at 10-50 $\times$ magnification.

The material used for data acquisition is a core section sampled in EPS-1 between 2158 and $2160 \mathrm{~m}$ depth and cuttings extracted from GPK-3 between 4700 and $4915 \mathrm{~m}$ depth (Figure 4). Hence, the data are representative of the deeper reservoir, around the major fracture. 


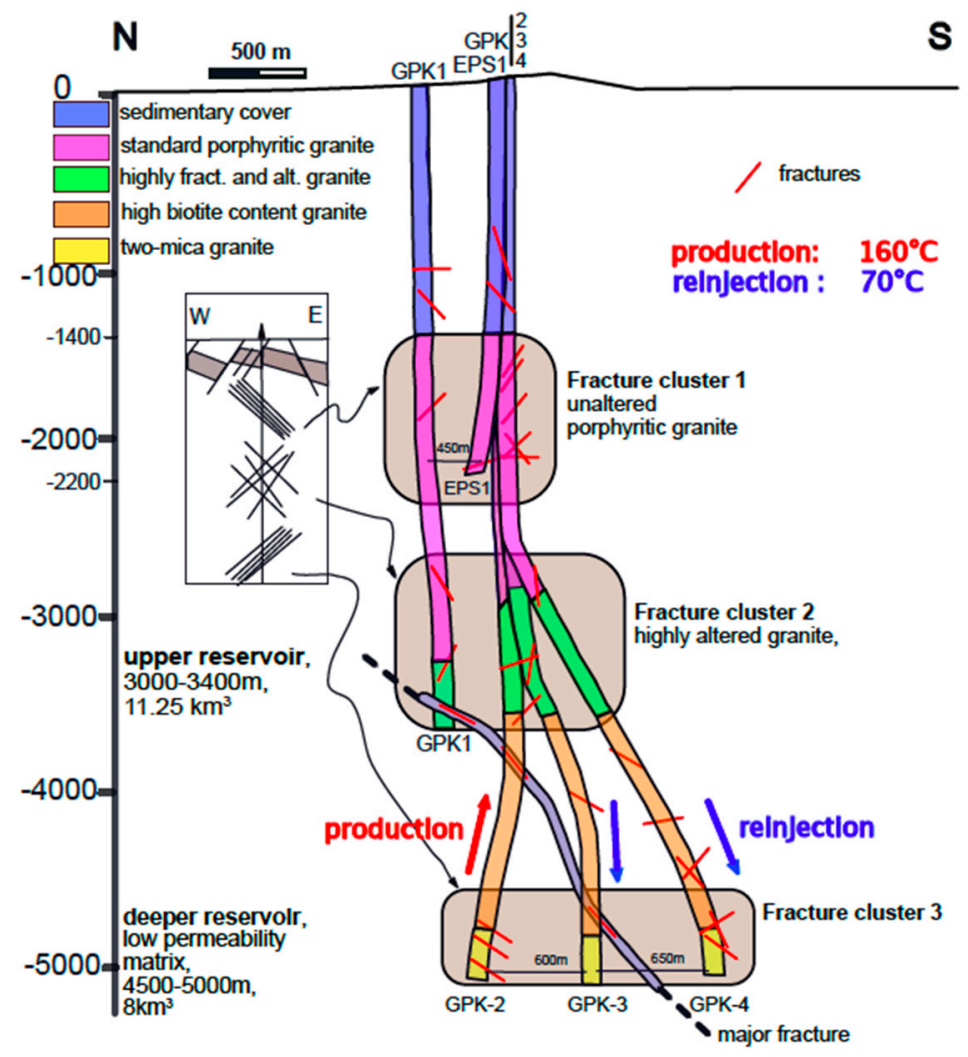

Figure 4. The Soultz EGS with the pilot plant composed of GPK-2, GPK-3 and GPK-4 (modified after [39]). $-1400 \mathrm{~m}$ : depth of the basement roof; $-2200 \mathrm{~m}$ : bottom of EPS-1 borehole. Standard porphyritic granite represents the fresh facies while highly fract. and alt. granite (highly fractured and altered granite) are the hydrothermally altered facies. Fracture clusters are described in $[38,39]$.

\subsection{Methods}

Detailed petrographical analysis was performed using polarizing optical microscopy (POM) on thin sections and cuttings. Microchemical analyses were performed on thin sections or core samples with a Camebax SX 50 microprobe equipped with four wavelength-dispersive spectrometers using the conditions specified by [40] for clay minerals.

Organic matter in the Soultz granite is not visible macroscopically. It can only be seen in thin sections in former plagioclase crystals by POM in natural light or by ultraviolet fluorescence. Gas chromatography, mass spectrometry and infrared spectroscopy were used to determine the nature of this organic matter [20]. Gas chromatography coupled with mass spectrometry (GC-MS) was used for the chemical characterisation of soluble organic matter in material sampled at $2158.80 \mathrm{~m}$ depth. The same analyses were also carried out on an oil sample extracted from the overlying fractured Buntsandstein layers (Figure 1), in order to compare the nature of organic compounds found in each environment (fracture zone in the sediments and in the granite). To analyse the organic matter in the granite, $418 \mathrm{~g}$ of rock were ground to a powder. Free lipids, soluble in organic solvents, were extracted with chloroform in a Soxlet apparatus. This organic fraction was analysed with a Packard 427 FID GC and a Finnigan Incos 500 GC-MS. The whole procedure is described in [20].

Dating by the K-Ar isotopic method was performed on authigenic illite extracted and separated from altered plagioclase crystals sampled at $2159.2 \mathrm{~m}$ depth in the EPS-1 borehole at Soultz. Plagioclase was gently reduced to powder, and then dispersed in distilled water. The suspension was separated into five size-fractions $(<0.1,0.1-2,2-5,5-10$ and $10-30 \mu \mathrm{m})$ by ultracentrifugation as generally used for clastic sediments [41,42], for altered igneous rocks [43], or for volcanics [44]. The technical procedure of K-Ar dating is similar to that described in [45]. The method is fully described by [46]. 
Microthermometry was performed on fluid inclusions in quartz crystals of a core sample collected in EPS-1 at a depth of $2159.13 \mathrm{~m}$ [47]. This sample was used to prepare a 200- $\mu \mathrm{m}$-thick wafer and analysed using a Chaixmeca heating and cooling stage [48] with a measurement accuracy of $\pm 0.2{ }^{\circ} \mathrm{C}$. It was calibrated using synthetic fluid inclusions. The whole procedure is described in [47].

Mercury porosimetry was performed on the same core samples to determine the petrophysical impact of hydrothermal alteration on the rock. The device used was a 2000 Carlo Erba porosimeter (injection pressure between 0.1 and 2000 bar), on whole-rock samples as well as separated plagioclase crystals to determine the fraction of whole-rock porosity due to altered plagioclases. The volume of the samples ranges between 0.2 and $1 \mathrm{~cm}^{3}$ for a $0.4-1.2 \mathrm{~g}$ mass. Plagioclase samples were obtained by cautious fragmentation of the rock, sorting of crystals under a binocular magnifier and XRD control. The whole procedure is described in detail by [26].

In the GPK-1 well, a pink coloration is locally developed when the Soultz granite is altered, and this is correlated with the variations in magnetic susceptibility and calcite content [39]. Thus, cutting samples from GPK3 in the deeper reservoir were systematically analysed by spectrophotometer using a Konica Minolta CM-2300d. This instrument provides measurements of the parameters: clarity $\left(\mathrm{L}^{*}\right)$, chroma $\left(c^{*}\right)$, hue $(h)^{*}$, green/red $\left(a^{*}\right)$ and blue/yellow $\left(b^{*}\right)$. Hue $\left(h^{*}\right)$ is found to show the maximum variation along the entire length of the boreholes and appears to be the most relevant parameter to describe the colour of the Soultz granite. This makes it possible to distinguish between fresh (grey) and altered (pink to reddish) facies. Therefore, hue was chosen as the most important parameter to be correlated with others. Measurements were carried out on finely ground cutting samples prior to the determination of calcite content, so these two parameters were determined on exactly the same sub-sample.

Calcite contents were determined using an OFITE 152-95 manocalcimeter for most of the analyses. Only $1 \mathrm{~g}$ of rock sample is needed to obtain a calcite content with a precision of around $0.5 \mathrm{wt} . \%$. The cutting samples were finely ground and exposed to $10 \% \mathrm{HCl}$ in excess to ensure complete dissolution. A high-precision manometer was used to measure the $\mathrm{CO}_{2}$ pressure in the cell. The experiments were performed in duplicate for each sample to calculate an average value. Each experiment lasted around $\frac{3}{4} \mathrm{~h}$ to ensure complete dissolution of the carbonates. The entire procedure is given by [33]. According to [49], the maximum calcite content of a fresh granite is $0.252 \mathrm{wt} . \%$ on average and does not exceed $1.8 \mathrm{wt} . \%$. The latter is called the fresh granite maximum value (FGMV) by [33]. As a consequence, each value higher than FGMV is considered as an anomaly representative of hydrothermal alteration and thus a sign of fossil or still-active fluid flow.

Magnetic susceptibility (MS) was evaluated with a Kappabridge KLY-4 Kappameter on a determined volume of cutting $\left(1 \mathrm{~cm}^{3}\right)$. Indeed, [50] and earlier studies [51-53] show that alteration strongly modifies the magnetic susceptibility of plutonic rocks, because of a lowered magnetite content. In particular, [53] worked on the Soultz granite. MS was measured directly on washed raw cutting samples, without any prior grinding. It is thus a rapid technique, compared to colorimetry and calcite content determination that require fine grinding.

Well data from drill holes were analysed from the literature to allow correlations with experimental data obtained in the laboratory, in order to determine flow pathways at Soultz. Data were also examined from the literature concerning the Rittershoffen geothermal site: temperature measurements in the drillholes, at $\mathrm{km}$ scale, high-resolution temperature measurements showing anomalies at the local scale (fractures and faults, fluid discharge, positive, negative or both, clearly visible at Rittershoffen).

\section{Results}

The results presented here were acquired by the authors on the Soultz site, either recently or in earlier studies. The Soultz geothermal reservoir is located in the deep granitic basement of the URG sedimentary basin (Figure 4) which is intensely crosscut by faults and fractures (up to 3000 fractures from 1400 to $2200 \mathrm{~m}$ depth in the EPS-1 well at Soultz, see [20,54] for their distribution in the borehole). The granite is strongly altered along these faults and fractures. The petrography of the fresh 
Soultz granite is briefly described below, followed by the hydrothermally altered facies to show the modifications affecting the fresh granite during alteration due to the circulation of hot fluids.

\subsection{Fresh Soultz Porphyritic Granite}

- Mineralogical composition of the Soultz granite.

The reference facies of the Soultz porphyritic upper granite (Figure 4) is composed of K-feldspar megacrysts set in a matrix of mm-sized quartz, plagioclase (oligoclase), K-feldspar, biotite and amphibole, with minor sphene and oxides. K-feldspar megacrysts are perthitic. This « fresh » granite shows evidence of only weak propylitization, as described by $[5,47,54]$. Amphibole and biotite are only slightly transformed into chlorite + carbonate \pm epidote or hydrogrossular, and plagioclase into calcite + corrensite or illite. The lower Soultz granite has a high biotite content and then, at the hole bottom, we encounter a two-mica granite, no longer porphyritic (Figure 4).

- Chemical composition

The chemical composition of the Soultz porphyritic granite (upper geothermal reservoir, Figure 4), is given in Table 2, where it is reported in the first column.

Table 2. Chemical composition of Soultz porphyritic granite: fresh facies (called Reference) and two altered facies (tosudite dominant and illite dominant). Modified after [47].

\begin{tabular}{cccc}
\hline Oxides (Weight \%) & Reference & Tosudite Alteration & Illite Alteration \\
\hline Loss on ignition & 0.81 & 4.05 & 7.49 \\
$\mathrm{P}_{2} \mathrm{O}_{5}$ & 0.14 & 0.21 & 0.38 \\
$\mathrm{SiO}_{2}$ & 67.30 & 63.80 & 54.80 \\
$\mathrm{Al}_{2} \mathrm{O}_{3}$ & 15.97 & 15.93 & 21.92 \\
$\mathrm{Fe}_{2} \mathrm{O}_{3}$ & 2.08 & 3.09 & 2.51 \\
$\mathrm{CaO}$ & 1.47 & 2.52 & 2.68 \\
$\mathrm{MgO}$ & 0.88 & 1.06 & 1.05 \\
$\mathrm{Na} 2$ & 3.57 & 1.50 & 0.57 \\
$\mathrm{~K}_{2} \mathrm{O}$ & 6.52 & 6.55 & 6.70 \\
$\mathrm{TiO}_{2}$ & 0.40 & 0.56 & 0.99 \\
$\mathrm{MnO}$ & 0.07 & 0.08 & 0.16 \\
$\mathrm{Density}$ & 2.66 & 2.47 & 2.00 \\
\hline
\end{tabular}

\subsection{Altered Soultz Porphyritic Granite}

At Soultz, hydrothermal fluids collected in the deep geothermal wells result from the mixing of primary marine seawater with water of meteoric origin $[13,14,55,56]$. These brines are of the $\mathrm{Na}-\mathrm{Cl}$ type with a high salinity (approximately $100 \mathrm{~g} / \mathrm{L}$ ), and $\mathrm{pH}$ close to $5[55,56]$. They circulate within the fracture network.

\subsubsection{Petrography}

The circulation of hot fluids within the granite has induced rock transformations. This kind of alteration, clearly developed in relationship with a fracture or group of fractures, is called vein alteration. Several episodes occurred during vein alteration, resulting in various features. One 1.6-m-long zone, located between 2158 and $2160 \mathrm{~m}$ depth, was studied in detail in the EPS-1 cores [46]. It belongs to a zone with high fracture density (2150-2180 m, Figure 5). The studied zone is developed on both sides of a quartz vein at a $2159 \mathrm{~m}$ depth $[6,20,47]$. This zone shows the partial to total dissolution of primary minerals (plagioclase, biotite, hornblende and locally quartz; [47] and the formation of secondary minerals including calcite [47], clay minerals (e.g., tosudite and illite [46] and oxides [5,57]. Plagioclase is replaced by tosudite (a mixed-layer clay mineral indicating a Li-rich fluid) and/or illite $[20,45,46]$. Table 2 gives the chemical composition of the granite affected by these two types of alteration (tosudite-dominant, illite-dominant) [20,46,47]. Illite is also found in veins crosscutting the altered granite. Organic matter is seen to impregnate tosudite patches and is later displaced by 
fluid circulation leading to the growth of illite in veinlets. Carbonates, found in association with tosudite and illite, are mostly Ca-bearing with minor amounts of Fe and Mg. Primary quartz is locally totally dissolved and newly formed quartz is found in veins with alteration developed on both sides (Ledésert et al. 1999; Bartier et al. 2008). In such rock samples, the porosity of the bulk rock reaches $25 \%$ [47], allowing present-day fluid flow as shown experimentally by [58].

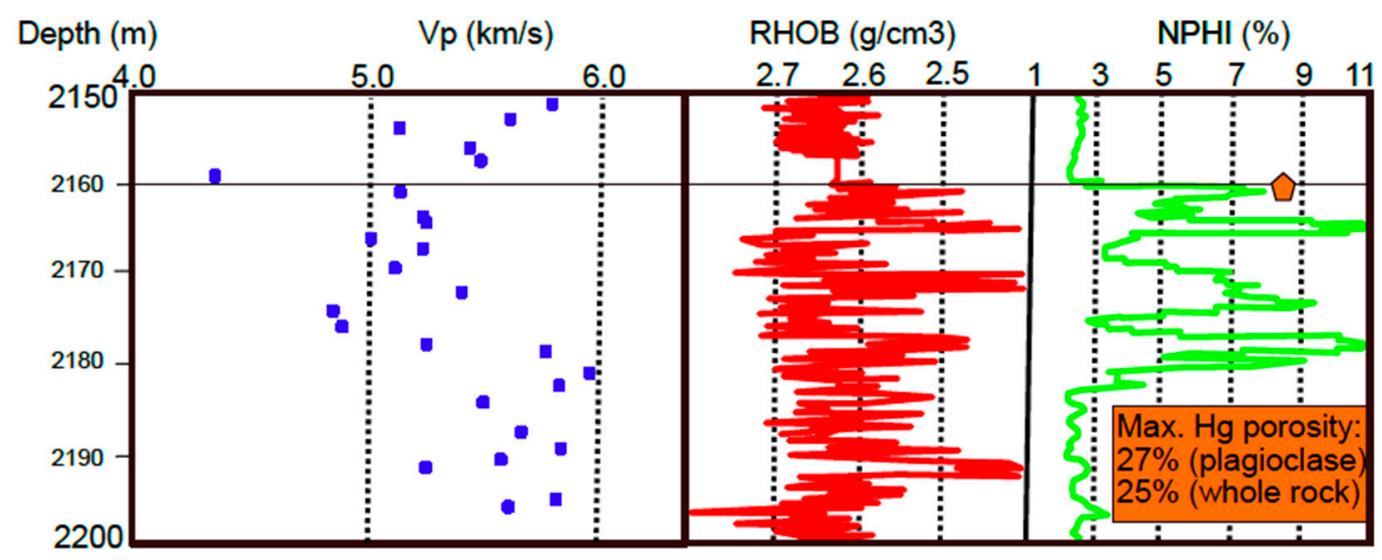

Figure 5. Parameters measured in borehole EPS-1: $\mathrm{P}$ wave velocity $(\mathrm{Vp})$, density (RHOB) and neutron porosity (NPHI). The maximum porosity measured by mercury porosimetry (Hg porosity) is also given for two samples (whole rock and isolated plagioclase crystals) in the altered zone is highlighted by an orange pentagon (ca. $2160 \mathrm{~m}$ ).

\subsubsection{Fluid Inclusions}

In the studied zone, fluid inclusions are found only in quartz crystals occurring as veinlets at 2159.13 $\mathrm{m}$ depth [47]. Temperatures of ice melting (Tm ice) are bimodal with modes at $-8.5^{\circ} \mathrm{C}(12.3 \mathrm{wt} . \% \mathrm{NaCl})$ and $-2.1^{\circ} \mathrm{C}(3.5 \mathrm{wt} . \% \mathrm{NaCl})$. Apart from two extreme values near $190^{\circ} \mathrm{C}$, homogenisation temperatures (Th) range from 120 to $160{ }^{\circ} \mathrm{C}$ with a mode at $135^{\circ} \mathrm{C}$. True trapping temperatures estimated by correcting the measured Th values for the pressure effect are about 10 to $12^{\circ} \mathrm{C}$ higher than the values obtained by homogenisation, giving a trapping temperature of about $145-147^{\circ} \mathrm{C}$ (value of the mode) [47].

\subsubsection{Illite Dating}

Illite was sampled in a vein associated with the quartz veinlet containing the studied fluid inclusions. This illite vein crosscuts the hydrothermally argillized granite. K-Ar dating indicates an illitization episode at $63 \mathrm{Ma}$ or slightly older for the coarsest particles $(10-30 \mu \mathrm{m})$ and an age of $18 \mathrm{Ma}$ or slightly younger for the smallest $(<0.1 \mu \mathrm{m})$. The intermediate fractions are interpreted as reflecting a mixing of two generations of illite [46]. The fluid-mineral interactions leading to the two illite precipitation episodes occurred in a temperature range of 120 to $160{ }^{\circ} \mathrm{C}$, on the basis of the fluid-inclusion microthermometry presented above. Hence, this provides information on both fluid temperature and salinity, as well as the age of the alteration.

\subsubsection{Organic Matter}

Organic matter is found as impregnations of tosudite that crystallised on the site of former magmatic plagioclase. It was later displaced and concentrated along veinlets in which illite (which was dated, see above) and carbonates have crystallised. The soluble organic matter extracted from the granite is composed of aliphatic acids, n-alkanes with a bimodal distribution centred on $\mathrm{C}_{18}$ and $\mathrm{C}_{24}-\mathrm{C}_{25}$ centred, alkylbenzenes and aromatic acids [20]. This organic matter can be compared to the oil produced by an artesian source, in a fractured zone of the sedimentary cover (Buntsandstein), that was encountered during drilling operations. Indeed, the Soultz site is only a few km away from Pechelbronn, the village that gave its name to the local oil field (Figure 2). The analysis of this oil reveals 
the presence of linear hydrocarbons (normal alkanes) centred on C17, branched alkanes with a major C19 peak, and few unsaturated hydrocarbons. The aromatic fraction is present in small amounts [20]. Plagioclase represents $40 \%$ of the whole granite volume. Mercury porosimetry performed on altered plagioclase transformed into tosudite indicates a porosity of up to $27 \%$. Thus, the pore volume in these altered facies accounts for up to $10-11 \%$ of the whole rock, which is, at least partly, occupied by organic matter.

\subsubsection{Chemical Composition}

The chemistry of the porphyritic granites shown in Table 2 indicates an increasing intensity of alteration from the Reference facies to illite-dominant through tosudite-dominant facies (Table 2). There is a growing depletion in $\mathrm{SiO}_{2}$ and $\mathrm{Na}_{2} \mathrm{O}$ that becomes very strong in illite-dominated alteration with a loss of more than $20 \%$ for $\mathrm{SiO}_{2}$ and even $84 \%$ for $\mathrm{Na}_{2} \mathrm{O}$. On the contrary, the $\mathrm{P}_{2} \mathrm{O}_{5}, \mathrm{CaO}$ and $\mathrm{TiO}_{2}$ contents increase by a factor $2.7,1.8$ and 2.5 respectively. $\mathrm{K}_{2} \mathrm{O}$ content remains globally constant, while $\mathrm{Al}_{2} \mathrm{O}_{3}$ first remains constant and then increases by a factor 1.37 . These data show that some elements are drastically extracted from the rock by the geothermal brine that circulates within the fracture system. The increasing alteration degree from the Reference facies to Illite-alteration is also shown by the drastic increase in loss on ignition by a factor 9.2 and decreasing density (factor 0.8 ; Table 2).

\subsubsection{Density, Porosity, Loss on Ignition}

High ROP was systematically recorded in the fractured and altered zones during drilling operations, indicating softer sections, as well as variations in parameters measured in the boreholes (P wave velocity, density, neutron porosity), as seen in Figure 5. Values for the freshest granite facies are as follows: $\mathrm{P}$ wave velocity $(\mathrm{Vp})$ around $6 \mathrm{~km} / \mathrm{s}$, density (RHOB) close to $2.65 \mathrm{~g} / \mathrm{cm}^{3}$, neutron porosity (NPHI) between 1.5 and $2 \%$. Vp is lowered where the rock shows low density values and high NPHI. A strong increase in NPHI is observed in EPS-1 between depths of $2160 \mathrm{~m}$ (with high values of porosity measured on samples in the lab, orange pentagon and associated values) and $2185 \mathrm{~m}$ (Figure 5). In some zones, NPHI values as high as $11 \%$ are obtained (2165 and $2185 \mathrm{~m}$ depths) while the density RHOB is lowered down to $2.4 \mathrm{~g} / \mathrm{cm}^{3}$ at 2172, 2185 and $2195 \mathrm{~m}$ depths. Low Vp values, down to $4.3 \mathrm{~km} / \mathrm{s}$, are encountered at $2160 \mathrm{~m}$ (with analyses performed in the lab) while other values lower than $5.2 \mathrm{~km} / \mathrm{s}$ are observed where values of density and porosity are the lowest. These strong variations in the tested parameters indicate a loss of matter during water-rock interactions implying a hot fluid (around $130-160^{\circ} \mathrm{C}$ ) with a high salinity (up to $12.3 \mathrm{wt} . \% \mathrm{NaCl}$ as recorded in quartz crystals) and reflected by the whole-rock geochemistry (see Table 2 above). This explains the porosity values of up to $25 \%$ reached by the bulk rock (and $27 \%$ for plagioclase transformed into tosudite) in the highly altered facies [47].

\subsubsection{Calcite Content, Colorimetry and Magnetic Susceptibility}

Carbonates are found in fractured and altered zones of the granite in well EPS-1, from 1400 to $2200 \mathrm{~m}$ depth. They are also found in the deep reservoir along the four deep drillholes GPK-1 to GPK-4 [39,47,59-61]. Figure 6 presents new data for GPK-3, which penetrates the deep reservoir containing the third fracture cluster (cluster 3, see Figure 4). Since the maximum calcite content in fresh granite is $1.8 \mathrm{wt} . \%$ [49], all values higher than $1.8 \mathrm{wt} . \%$ are considered as anomalous because of the hydrothermal alteration. In the cluster 3 zone, a clear correlation can be seen between the carbonate content, the hue and the MS of the granite, even though some irregularities are observed. The correlation is positive between calcite content and MS, while it is mostly negative versus MS and hue. These correlations are particularly visible in the orange rectangles (Figure 6). Two fracture zones were identified during drilling or production/injection tests. They are not correlated with intense calcite anomalies, but show rather high values of hue and low MS where this measurement is available. 


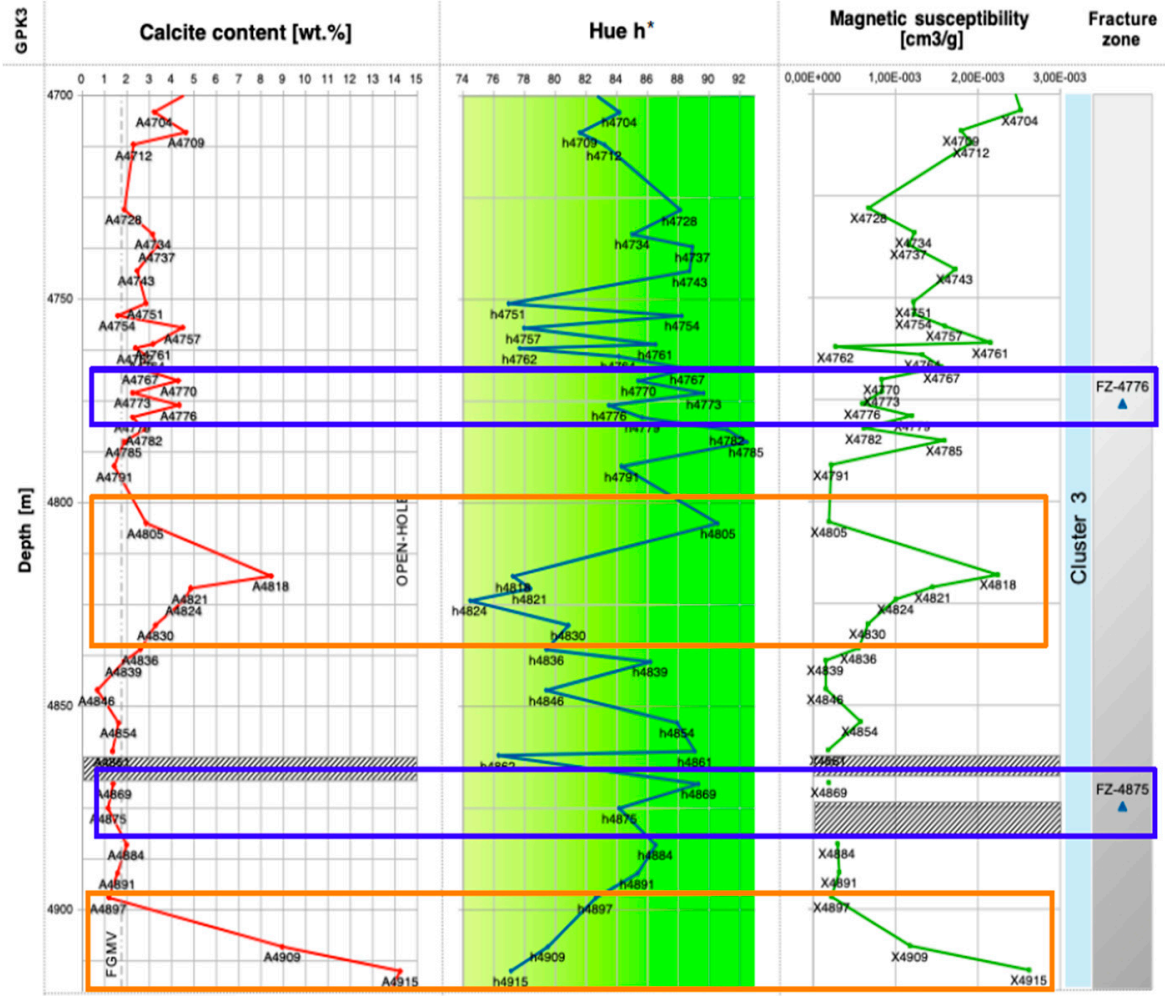

Figure 6. Calcite content, hue and magnetic susceptibility of granite samples in the third fracture cluster (cluster 3, Figure 4) encountered in the deep reservoir, in well GPK-3. Two fracture zones are present (FZ-4776 and FZ-4875), highlighted by blue rectangles. Orange rectangles highlight zones in which the correlation between the three parameters is particularly visible. Grey dashed zones indicate that no samples are available.

\section{Discussion}

The following discussion is based on literature data at the scale of the URG and on experimental data obtained at Soultz, which are then compared to those related to Rittershoffen taken from the literature.

\subsection{Origin of Thermal Anomalies}

From a general point of view and from thermal modelling, [62] states that the main factors controlling the thermal field in the upper $5 \mathrm{~km}$ of the URG are: (1) The thickness of unconsolidated Cenozoic rift sediments; (2) variations in radiogenic heat production of upper crustal domains; (3) the thickness distribution of the upper crystalline crust; (4) the depth of the thermal Lithosphere-Asthenosphere Boundary and (5) the thickness distribution of consolidated sediments. Based on thermo-hydro-mechanical modelling, [63] reported N-S convection cells characterised by a regular pattern of graben-parallel thermal anomalies associated with major N-S-striking faults showing a higher permeability. These features represent small-scale temperature anomalies in the URG that have been ignored in previous models based on 2D E-W-striking sections. More recently, and based on thermo-hydro modelling, [24] indicates a gravity-driven migration of fluids from the shoulders to the centre of the URG, implying west-east or east-west transfers. At Soultz, hydrothermal convection may explain 75-85\% of the thermal anomaly [64], and the up-flow of thermal water occurs mainly along westward-dipping normal faults [65]. The remaining $15-25 \%$ might be explained by the radiogenic heat production because of the composition of the granitic basement [64]. In GPK-1, at depths between 1400 and $1550 \mathrm{~m} \mathrm{MD}$, the radiogenic production has been determined on core samples [66]. It ranges between 5.5 and $6.5 \mu \mathrm{W} / \mathrm{m}^{3}$. Continuous logging of the deep geothermal well GPK-2 has provided 
values of up to $7 \mu \mathrm{W} / \mathrm{m}^{3}$ between 3700 and $3800 \mathrm{~m}$ MD and at $5060 \mathrm{~m}$ MD in permeable zones [66-70]. In a different geological context, thermohaline stratification in mine waters has been reported and modelled via double-diffusive convection for geothermal energy recovery from flooded mines [71]. To our knowledge, such a stratification phenomenon has not been reported in the URG.

\subsection{Temperature Measurements in Geothermal Wells}

- Global temperature gradients from geothermal wells

Temperature data measured at several geothermal sites in the URG were compiled by $[13,17]$. These present-day temperature measurements are indeed consistent with calculations of [12], as they indicate maximum temperatures at Soultz of around $200{ }^{\circ} \mathrm{C}$, compared with $230{ }^{\circ} \mathrm{C}$ estimated by geothermometers deeper in the URG (Figure 1). Figure 7 presents the temperatures measured in the wells from north (Brühl) to south (Basel, Figure 2) of the URG. The temperatures measured in wells yield the profiles given in Figure 7, always with a variation of gradient in the sedimentary cover. At Rittershoffen (GRT1 well), for example, below the top Muschelkalk, the temperature profile changes drastically and the rate of change becomes very weak, around $3{ }^{\circ} \mathrm{C} / \mathrm{km}$, which is about 30 times smaller than in the upper part of the well [16]. However, it is easily seen that the temperature gradient is not the same at every location: it is linear down to $3500 \mathrm{~m}$ at Brühl, but shows a strong break in slope close to the surface (1400 m depth) at Soultz or deeper (around $2000 \mathrm{~m}$ ) at Rittershoffen (Figure 7). Furthermore, the rate of change of the gradient varies from one site to another, from very steep (Brühl, Basel) indicating a rather low to smooth gradient at Soultz and Rittershoffen where the gradient is steepest, with intermediate gradients being encountered at landau, Bruchsal and Cronenbourg (Figure 2). These variations are explained, at least in part, by the geometry of the graben (Figures 1 and 2) and by the proximity of faults (Soultz fault and Rittershoffen fault, for example) [11,14-16], that might correspond to the location of N-S convection cells [63]. In addition, gradient changes usually occur because of conductive and convective phenomena. On the one hand, differences in thermal conductivity occur in the Basel borehole, for example, where a higher gradient is recorded in the upper part compared with the lower part. This is because of lower conductivity in the sediments than in the granitic basement; as a result, no convection is encountered and the temperature profile is rather homogeneous. On the other hand, convection occurs at Soultz or Rittershoffen, resulting in rather low gradients and a strong discrepancy between temperature profiles in the basement and its sedimentary cover.

- High-resolution temperature measurements in geothermal wells

In addition to the general thermal profiles presented in Figure 7, high-resolution temperature data from wells in several sites in the URG reveal a spatial link between anomalously high temperature and local faults, such as at the Soultz, Rittershoffen (Figure 8) and Kutzenhausen faults, as well as at the $\Omega$-fault in Landau [18]. At these sites, geothermal anomalies at the local scale are attributed to buoyancy-induced hydrothermal circulation in fractures within the crystalline basement and overlying sandstones [18].

An example of such local anomalies is given in [10] for the Rittershoffen wells GRT-1 and GRT-2 that were drilled in 2012 and 2014, respectively, in the framework of the ECOGI project. These two wells provide high-quality datasets on a deep geothermal system in the URG, at the transition between the Buntsandstein sandstone and the Palaeozoic granitic basement. Well GRT-1 was drilled nearly vertical while well GRT-2 was drilled parallel to the Rittershoffen fault, in its damage zone. GRT-2 is used as a production well. At its bottom, the temperature reaches $177^{\circ} \mathrm{C}$ at a measured depth (MD) of $3196 \mathrm{~m}$ at thermal equilibrium. Reinjection is performed in GRT-1. The general shape of both temperature profiles in GRT-1 and GRT-2 suggests a diffusive temperature regime from the ground surface to the top of the Muschelkalk formation (Figure 7). An advection-dominated temperature regime is then found below the top Muschelkalk, as already proposed for the Soultz reservoir [72]. This suggests that the Keuper formation acts as a hydraulic barrier, being mainly composed of clays and dolomites located directly above the Muschelkalk (Figure 7). Indeed, the slope change in the 
temperature profiles is very sharp. This observation supports the existence of a caprock barrier. At Soultz-sous-Forêts, hydrothermal convection cells decrease significantly in importance above the Buntsandstein-Muschelkalk, which implies a major sealing quality of the clayey Liassic Black Shales and overlying Tertiary marls with significantly lower hydraulic conductivities compared to the fractured Buntsandstein, Muschelkalk and Keuper formations [30,69,72].

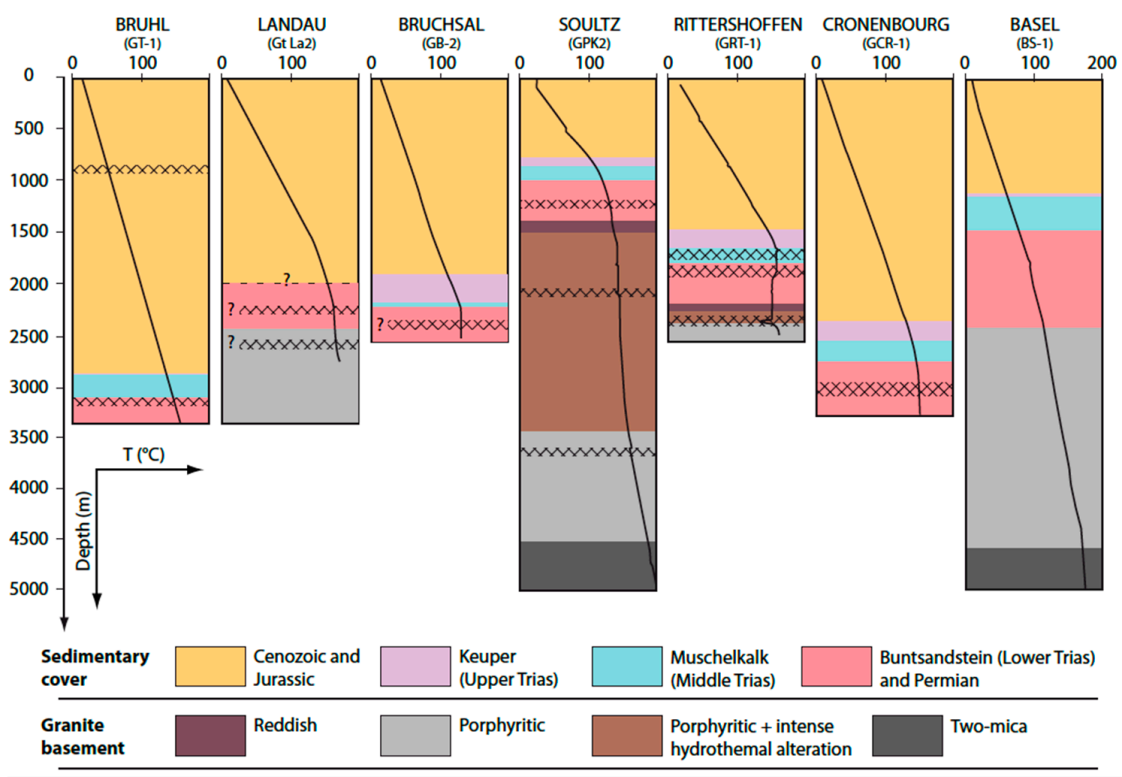

$x x x x x x x x x x x y$ Permeable fracture zone observed along borehole

Figure 7. Synthesis of thermal profiles from north (Brühl, Germany) to south (Basel, Switzerland) in the URG, including the Soultz and Rittershoffen sites in France. The gradient generally shows a slope variation within the sedimentary cover. Modified after [17].

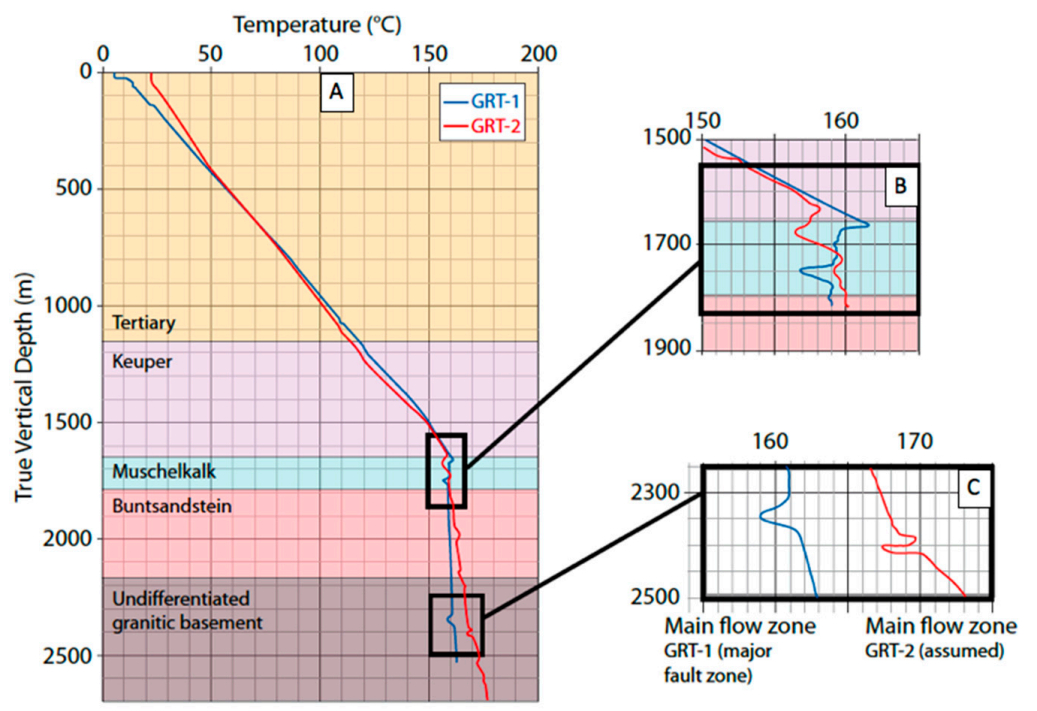

Figure 8. High-resolution temperature profile (A) in both GRT-1 and GRT-2 wells at Rittershoffen, modified after [10]. The general thermal gradient shows a slope break at the boundary between Muschelkalk and Keuper. Local-scale major temperature anomalies are highlighted in small rectangles in the Muschelkalk (B) and in the granite (C).

From a global point of view, the thermal gradient at Rittershoffen is very high in the sedimentary cover, including the Keuper, and then becomes much lower from the Muschelkalk down to the bottom 
of the wells. The situation is rather different in the two wells, GRT-1 and GRT-2 (Figure 8A). The thermal gradient in GRT-1 is higher from the surface to the top of the Muschelkalk, but higher in GRT-2 from the top of Muschelkalk to the bottom of the well. Two strong thermal anomalies are identified in the Muschelkalk and in the granite (Figure 8B,C). Secondary local anomalies are also encountered within the Buntsandstein and at the very top of the granite (Figure 8A). All these anomalies appear as being positive (temperature higher than normal) or negative (temperature lower than normal) or both (Figure 8C, GRT-2 well). According to [16], these anomalies possibly indicate significant natural fluid circulation. Indeed, severe mud losses occurred in the Muschelkalk during the drilling of GRT-1. On the contrary, no drilling mud losses were reported in GRT-2 in the Muschelkalk, in spite of high ROP observed during drilling operations [9] indicative of fractured and altered zones [5]. In the Buntsandstein, an anomaly is identified in GRT-2 at around $1980 \mathrm{~m}$ TVD, whereas little or no significant anomaly can be seen in GRT-1. In the granite, an important negative temperature anomaly estimated at around $-2.5^{\circ} \mathrm{C}$ [9] is located in GRT-1 at around $2350 \mathrm{~m}$ TVD (Figure 8C). Spinner logs performed during a production test indicate that this anomaly is correlated with a production zone [10]. Well image analysis also confirms the existence of a major fractured zone at that depth [15]. The strongest temperature anomaly in the open-hole section of GRT-2 is observed in the granite section between $2400 \mathrm{~m}$ TVD and $2415 \mathrm{~m}$ TVD [15], as shown in Figure 8C. The total amplitude of this anomaly is almost $-3{ }^{\circ} \mathrm{C}$. A nearly $+2{ }^{\circ} \mathrm{C}$ positive anomaly is located just above (2380 $\mathrm{m}$ to $2400 \mathrm{~m}$ TVD). According to [10], this succession suggests a strong lateral variability of the natural flows, and therefore the channelling, related to large open fractures.

\subsection{Petrography of Fractured and Altered Zones, Their Stimulation and Implications on Temperature Distribution at a Local Scale}

At Soultz, the circulation of hot fluids has induced a strong alteration of the granite in the vicinity of faults and fractures acting as channels $[33,54]$. This circulation is locally still active and represents flow pathways favourable for the geothermal power plant. The alteration process is characterised by the partial to total dissolution of primary magmatic minerals in the granite (plagioclase, biotite, hornblende and locally quartz; [47]) and the formation of secondary minerals including calcite [33,47,60], clay minerals (e.g., tosudite and illite [46]) and oxides [54,55]. Trapping temperatures in the range $145-147^{\circ} \mathrm{C}$ (value of the mode) were obtained by microthermometry on fluid inclusions in the altered zone [46]. These values are identical to the temperatures encountered at present at the same depth. Together with salinities in the range 3.5 to $12.3 \mathrm{wt} . \% \mathrm{NaCl}$, these features indicate that the paleo-fluids circulating $63 \mathrm{Ma}$ and $18 \mathrm{Ma}$ ago (according to K/Ar dating of illite [45], see above) have characteristics similar to the present-day fluids. These data were obtained on a single 2-m-long highly altered section located close to the bottom of EPS-1 well, yielding results that are in good agreement with those obtained by $[73,74]$ all along the same borehole. For example, according to [73], trapping temperatures obtained by correction of the homogenisation data for a hydrostatic pressure of 164 bar (1640 m depth) range between 144 and $159{ }^{\circ} \mathrm{C}$ (measurements on fluid inclusions in quartz crystals. In ankerite also sampled from EPS-1, the same authors [70] report homogenisation temperatures between 137.5 and $158^{\circ} \mathrm{C}$, consistent with those found in quartz crystals developed in quartz veins located at $1369 \mathrm{~m}$, $1430 \mathrm{~m}, 1607 \mathrm{~m}, 1639 \mathrm{~m}, 2001 \mathrm{~m}, 2148 \mathrm{~m}$ and $2174 \mathrm{~m}$ depths in the same drill hole [47,74,75]. The shape and temperature data of fluid inclusions in carbonates indicate that they have not been disturbed since their formation in spite of their high sensitivity to changes in environmental conditions [73]. Hence, it is likely that quartz and carbonate veins are still forming at present in the URG basement. Indeed, based on thermodynamic calculations, [76] shows that calcite, illite and quartz, among other minerals, may be precipitated when the temperature is lowered, around reinjection wells for example. Thus, the fluids that circulated in the fractured upper Soultz granite all along EPS- 1 borehole are similar to those still flowing at present.

In the zone studied by $[45,46]$, organic matter has been found [20] with two different compositions (see Results section) that would either originate from a single source (immature sediments) or from two 
sources (immature sediments and migration of the Pechelbronn oil). No real evidence has been found to show which hypothesis to favour. However, the nature of the organic compounds gives an indication of the maturity of the formation from which they originated. According to [77], Upper Oligocene and younger rocks are immature in terms of organic matter in the Soultz area. At least a part of the organic matter found in the granite would thus originate from these shallow levels. In addition, the Pechelbronn oil field (a few km away from Soultz, Figure 2) hosts hydrocarbons that circulate in the fracture zones and these compounds have been sampled during drilling operations at Soultz. At this site, the best candidates for source rocks are of Toarcian age. Migration phenomena have been identified in faulted zones which affect the Muschelkalk [77]. Since the Upper Oligocene and younger levels are immature in terms of organic matter [77], at least part of the organic matter found in the Soultz granite could originate from these Tertiary levels. Tertiary reservoirs have produced $97 \%$ of the amounts of oil and the Jurassic reservoir only 3\% [10]. From these observations, we can assume that organic matter has migrated from its traps into the granite according to the scheme shown in Figure 9.

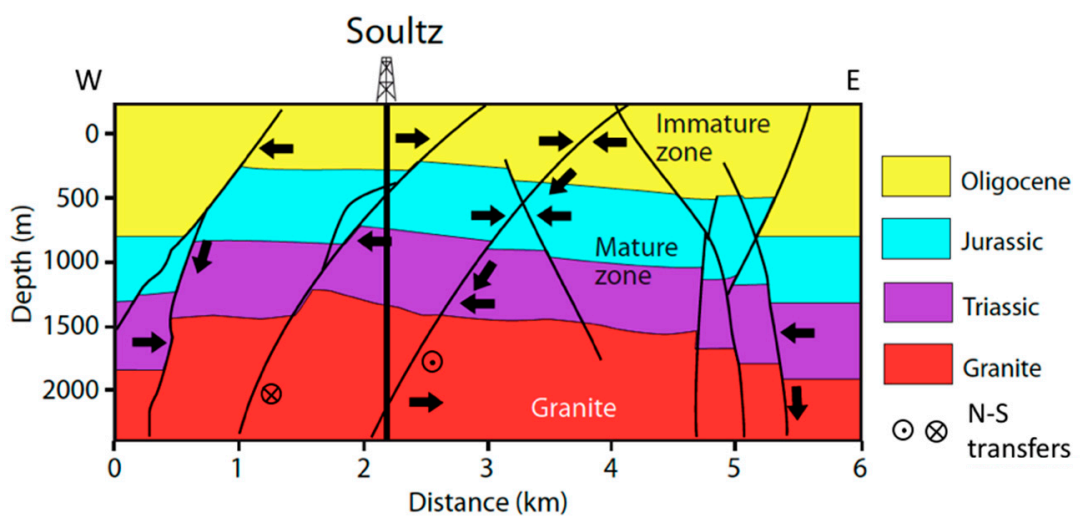

Figure 9. Scheme of organic matter migration from immature and mature zones of the sedimentary succession based on the nature of organic compounds found in the granite at a $2160 \mathrm{~m}$ depth. Modified from [20] and including data from [63].

Spatial variations of gravity measurements have been modelled in 2D and 3D by [78]. Their approach was to quantify gravity anomalies related to the deep hydrothermal circulation using thermo-hydro-mechanical modelling. A finite-element method was used to compute the large-scale hydrothermal circulation based on the variations of effective density. The circulation is shown to be mostly linked to the convective system with a wavelength of about $7.5 \mathrm{~km}$, consistent with the width of the hydrothermal convection cells. The anomaly maximum is said to be located at the top of the maximum surface heat flux. As a consequence, the interpretation of [20] concerning organic matter migration (Figure 9) seems well founded but does not exclude longer-distance migration patterns.

According to [79], injection tests indicate natural velocities of the order of $1 \mathrm{~km} / \mathrm{yr}$. Hence, the transfer of organic matter from mature and immature horizons might have been very rapid, resulting in the preservation of immature organic compounds. The $63 \mathrm{Ma}$ or slightly older age found for illite containing immature organic matter at $2160 \mathrm{~m}$ depth in the Soultz granite might be related to the higher heat flows that occurred at the beginning of the rifting event at about $70 \mathrm{Ma}$, as reported by [24].

At Soultz, we find (see Results section) that altered zones in the well GPK-3 can also be characterised by their colour (hue, $\mathrm{h}^{*}$ parameter), calcite content and MS, and that these parameters are intercorrelated. Indeed, [50] and previous authors [51-53] showed that alteration strongly modifies the magnetic susceptibility of plutonic rocks, as a consequence of a lowered magnetite content. In particular, [53] specifically investigated the Soultz granite and showed that changes of magnetic properties occur during the progressive fracturing and hydrothermal alteration of the granite after its emplacement. The magnetic susceptibility of the fresh granite is between $10 \times 10^{-3}$ and $80 \times 10^{-3} \mathrm{SI}$, suggesting that ferrimagnetic minerals are the primary carrier [53]. According to [53], after cooling 
the granite was transformed during tectonic and hydrothermal activities, inducing oxidation of magnetite to hematite with reduced MS $\left(<1 \times 10^{-3} \mathrm{SI}\right)$. In addition, the anisotropy of MS shows that the geometry and orientation of the magnetic fabric is clearly related to the tectonic stresses during the post-emplacement history of the Soultz granite. Indeed, in GPK-1 where cuttings represent the great majority of samples available, no ASM data were available and only MS was measured. According to [39], high calcite contents in GPK-1 are correlated with the abundance of clay minerals and low Young's modulus, as well as variations in spectral gamma-ray log and low MS; all these parameters indicate strong hydrothermal alteration. However, data obtained for GPK-3 show high MS values when the calcite content is high (see Figure 6). Indeed $[59,80]$ showed that calcite content strongly varies among the altered zones and among wells and cannot be directly related either to the intensity of hydrothermal alteration or to the present-day permeability.

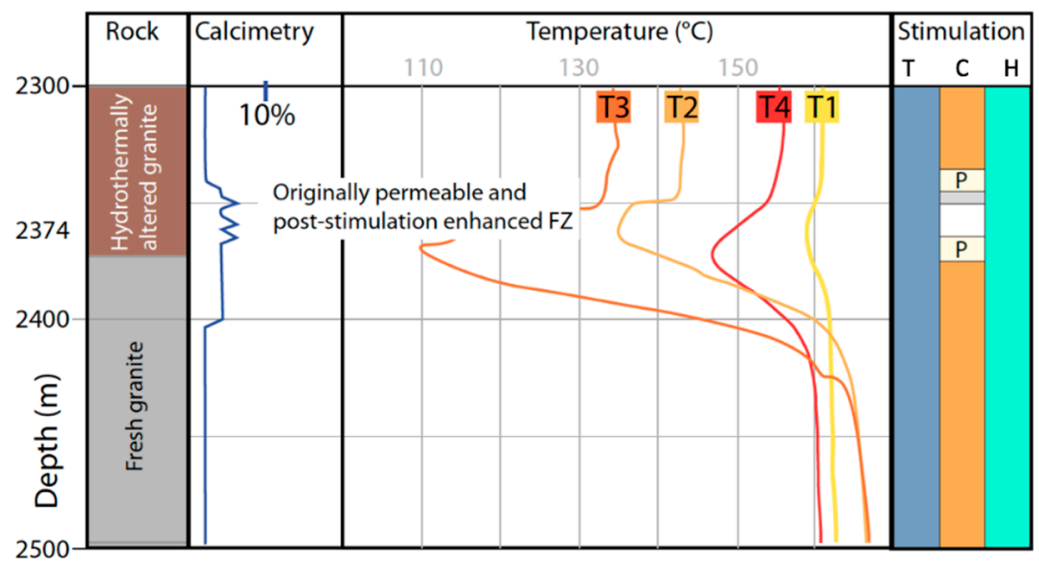

Figure 10. High-resolution temperature profile in the GRT-1 well at Rittershoffen before (T1) and after (T2 to T4) stimulation. A negative temperature peak is observed at the depth where an anomaly in carbonate content occurs, at the border of a hydrothermally altered zone. Stimulation: blue $=$ thermal $(\mathbf{T})$, orange $=$ chemical $(\mathbf{C})$, green $=$ hydraulic $(\mathbf{H})$. P: packers. $($ modified after [9]) .

Calcite content determination is a key point for geothermal projects because this mineral can be rather easily dissolved during stimulation operations. In EGS sites, fracture zones are thermally, hydraulically or chemically stimulated in order to increase their permeability. A good example of stimulations and their effect on fluid flows and temperature anomalies is given in [9] at Rittershoffen. Three kinds of stimulations were performed: thermal, chemical and hydraulic (TCH stimulations), each of these procedures consist of injecting fluids with different physico-chemical characteristics from the surface. Temperature monitoring was performed before and after each of the stimulations (Figure 10). Here, we focus on the deepest hydrothermally altered zone encountered in the granite body in well GRT-1, where a small thermal anomaly correlated with a calcite anomaly was observed before the stimulations (Figure 10, T1). Thermal treatment consisted of injecting $4300 \mathrm{~m}^{3}$ of water at surface temperature into the hot reservoir to promote thermal microcracking. This resulted in increasing the permeability along the well and the connectivity with the reservoir [9]. It also increased the negative thermal anomaly by around $10{ }^{\circ} \mathrm{C}$ (Figure 10, T2). An injection test was performed after the stimulation, followed by chemical treatment with the chelating agent GLTA which targeted minerals such as carbonates or sulphates plugging the fracture zones. The chemical treatment was constrained by packers in the zone of interest. This again led to an increase in the thermal anomaly (Figure 10, T3). Finally, hydraulic stimulation was performed by injecting a large amount of water at a high flow rate to increase the pore pressure within the rock mass. This resulted in the shearing of existing weak fractures or creation of new ones [9], and an increase in the negative thermal anomaly compared to the initial profile (Figure 10, T4). After the TCH treatments, the injectivity of well GRT-1 increased five-fold [9]. All of the treatments induced a cooling of the zone, indeed indicating that the 
rock mass is permeable like many of the fractured and hydrothermally altered zones in the granite, especially after stimulation.

Hence, based on the Soultz and Rittershoffen examples, the general thermal gradient in the URG appears to be locally modified by fluid flows channelled within fractured and altered zones, either in the sedimentary cover or its granitic basement. The zones affected by intense hydrothermal alteration are usually the seat of present-day hot fluid flow. Hence, measuring the petrographic (in particular calcite content), magnetic and petrophysical characteristics of altered zones is a key point for the understanding of natural flow systems in the URG and for the development of geothermal programmes.

\subsection{Integration of Results}

Organic matter in the URG gives an insight into the evolution of temperature with time. Kitchen areas in the Posidonia Shale of Toarcian age indicate a temperature of $80-90{ }^{\circ} \mathrm{C}$, during late Cretaceous [30], that was possibly influenced by higher heat flows at the onset of the rifting event, at about $70 \mathrm{Ma}$ [30]. In the deepest areas of the URG, the maximum temperatures during upper Oligocene to Miocene times greatly exceeded those attained during the Cretaceous [22]. The highest maturity levels encountered correspond to the wet gas window (up to $150^{\circ} \mathrm{C}$ at a $5 \mathrm{~km} \mathrm{depth).} \mathrm{At} \mathrm{present,}$ at Soultz, the measured temperature is $200^{\circ} \mathrm{C}$ at a $5 \mathrm{~km}$ depth where the brine is collected for geothermal purpose. In the URG, oil reservoirs typically occur in formations beneath major transgressive surfaces acting as efficient seals and on the up-thrown side of tilted fault blocks, mostly within Tertiary strata (Pechelbronn oil field, for example). [31,32] not only reported lateral migration of oil, but also its occurrence above the seals, indicating migration via faults. In addition, Ref [23] modelled fluid flow within the URG and showed the efficiency of faults to conduct fluids. Indeed such migration is evidenced in the Soultz granite, where organic matter of both mature (oil) and immature (shallower source) types is encountered at a $2.2 \mathrm{~km}$ depth in EPS- 1 drillhole. At this depth, the granitic basement is highly fractured and altered. Hence, the presence of organic matter in the granite shows the importance of fluid flows through major fractures, at the kilometre scale, between the sedimentary cover and the granitic basement. In addition, the impregnation of plagioclase pseudomorphs with organic matter is made possible because of their high interconnectivity, the intergranular micro-fracturing of the granite $[20,47,59]$ and hence the circulation of hydrothermal fluids at the micrometre scale. Porosity and thermal conductivity measurements performed on samples of various facies of the Soultz granite [81] provided thermal conductivity ranging from $2.3 \mathrm{~W} \cdot \mathrm{m}^{-1} \cdot \mathrm{K}^{-1}$ to $3.9 \mathrm{~W} \cdot \mathrm{m}^{-1} \cdot \mathrm{K}^{-1}$. A global trend is observed of decreasing thermal conductivity with increasing porosity between 0.9 (fresh granite) and 10\% (highly altered facies). [82] showed the same relationship. High thermal conductivity values in very low porosity samples are probably due to cementation of the crack network. Indeed, the thermal conductivity of quartz, reaching up to $6.5 \mathrm{~W} \cdot \mathrm{m}^{-1} \cdot \mathrm{K}^{-1}$, is higher than the average value for the whole rock: $3.2 \mathrm{~W} \cdot \mathrm{m}^{-1} \cdot \mathrm{K}^{-1}$. Samples with a relatively high porosity and high thermal conductivity are those containing quartz-sealed fractures, quartz-cemented matrix and open cracks in which the geothermal fluid circulates. As a consequence, and according to [81], thermal conductivity is directly correlated to mineralogy at Soultz. [83] shows the importance of such measurements to assess the energy reserve of a geothermal reservoir. From the above considerations [80], it appears that thermal conductivity combined with petrography, mineralogy and fracture analysis $[6,20,33]$ might provide a good indication of potential present-day fluid flows occurring in altered granite zones. This is one of the key issues of geothermal prospection. In addition, [84] indicates that the precipitation of newly formed minerals and in particular clays during hydrothermal alteration has a large effect on the geomechanical properties of a geothermal reservoir. The identification and characterisation of such zones is a second key issue for geothermal projects, for the reduction of induced seismicity during hydraulic stimulation of a reservoir. 


\subsection{Extrapolation to Other Sites in France}

Other areas in France show thermal anomalies like the URG (Figure 11)—even though somewhat less intense (Bresse and Rhône grabens)—owing to their similar geological context, namely grabens. This is why these sites are also being investigated in the framework of EGS geothermal programmes, in particular the Limagne Graben and the Rhône Graben (Figure 11, LG and RG).

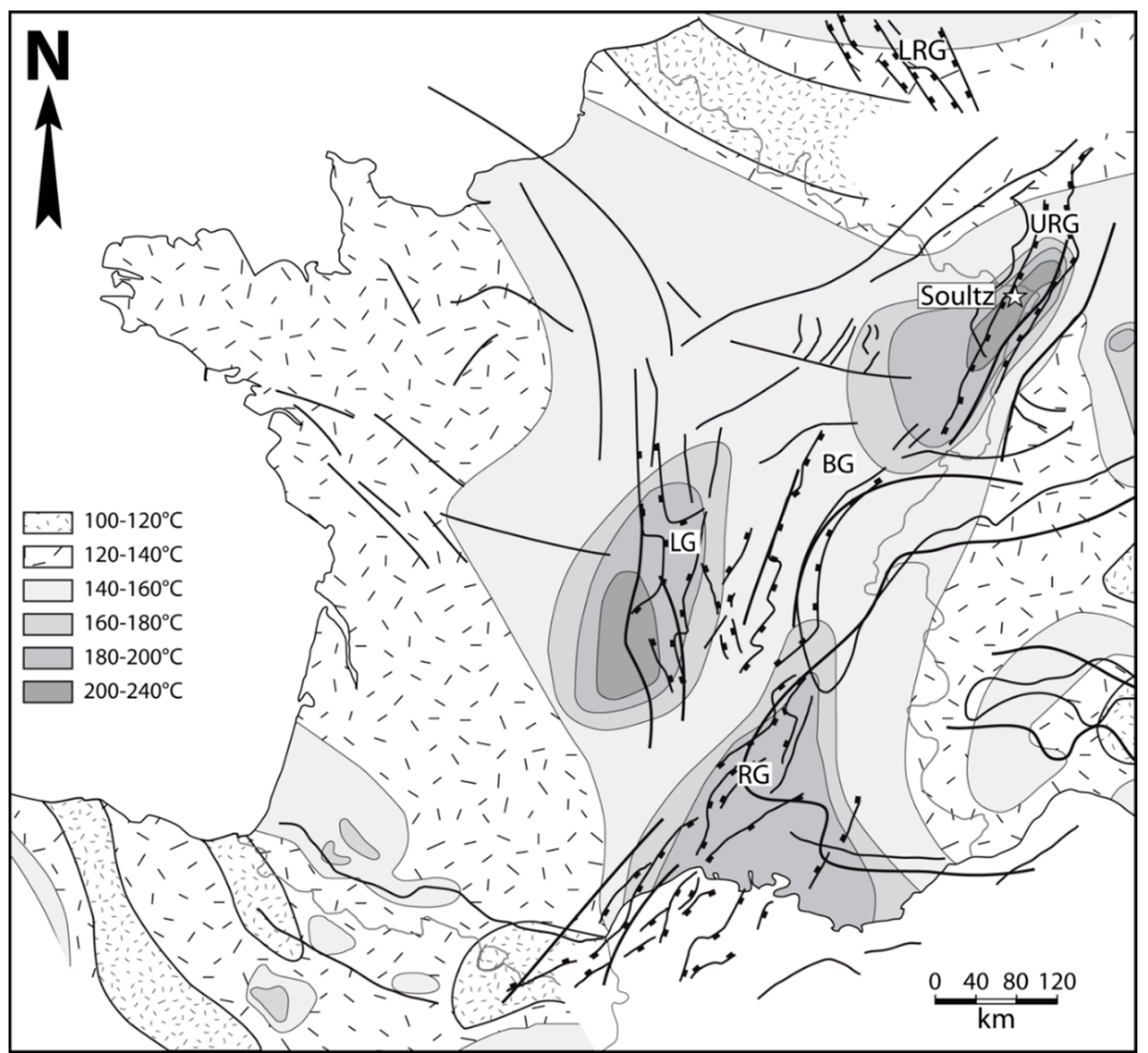

Figure 11. Thermal anomalies in France at 5km depth. From north to south: LRG: Lower Rhine Graben, URG: Upper Rhine Graben, BG: Bresse Graben, LG: Limagne Graben, RG: Rhône Graben. Modified after [80].

\section{Conclusions}

The temperature distribution of the URG is investigated at various scales, from the kilometre down to the micron. The kilometre-scale is studied using temperature measurements in geothermal wells, showing that the thermal gradient is not homogeneous, and that the transfer of organic compounds from the sedimentary cover to the granitic basement may have occurred very rapidly. The metre-scale observations are based on thermal anomalies encountered in the geothermal wells during drilling or stimulation operations. The micrometre-scale is investigated through petrography and particularly the study of fluid inclusions and the dating of the hydrothermal alteration responsible for their formation, as well as the analysis of organic matter found in the granitic basement.

The thermal gradient is very high (up to $110^{\circ} \mathrm{C} / \mathrm{km}$ ) in the sedimentary cover, while it is very low (down to $3{ }^{\circ} \mathrm{C} / \mathrm{km}$ ) in the granitic basement, depending on the location of the studied sites within the URG. Given all the data presented here, the Triassic Buntsandstein in the graben centre, at depths $\geq 4 \mathrm{~km}$, could be the potential reservoir for the geothermal brine circulating in the granite at its NW external border. This brine would have equilibrated with sedimentary rocks at $230 \pm 20^{\circ} \mathrm{C}$, as estimated 
from chemical and isotope geothermometers [18]. These data are in accordance with [10] who indicated that the tertiary sedimentary formations exhibit exceptionally high temperature gradients up to $100{ }^{\circ} \mathrm{C} / \mathrm{km}$ and also hosted hydrocarbons, such as at Pechelbronn (Figure 2).

This paper shows how geothermal operated sites can help in deciphering the thermal profile in the URG and identifying structures responsible for fluid circulation in the basement. Such zones are the seat of very local temperature anomalies, either positive or negative, identified during drilling operations or just after, which are linked with present-day fluid flows. Further work will be focused on a more detailed description of these fracture zones and correlations between the four deep drillholes at Soultz. Ref [23] points out that a knowledge of temperature distribution is crucial for geothermal purposes since it can be used to infer heat transfer processes and, thus, hydraulic conditions which are very important for geothermal programmes. It is therefore very important to ascertain the temperature distribution in the URG at both regional and local scales for present and future geothermal developments.

Author Contributions: Conceptualisation, B.A.L. and R.L.H.; methodology, B.A.L.; validation, R.L.H. and H2020 MEET consortium.; formal analysis, B.A.L. and R.L.H.; investigation, B.A.L and R.L.H.; resources, R.L.H.; data curation, B.A.L and R.L.H..; writing-original draft preparation, B.A.L.; writing-review and editing, R.L.H. and H2020 MEET consortium; visualisation, R.L.H.; supervision, B.A.L.; project administration, B.A.L.; funding acquisition, B.A.L. and H2020 MEET consortium. All authors have read and agreed to the published version of the manuscript.

Funding: This project has received funding from the European Union's Horizon 2020 research and innovation programme under grant agreement No 792037 (MEET project).

Acknowledgments: The authors are grateful to GEIE EMC for giving access to cutting samples and geophysical logs from the Soultz-sous-Forêts geothermal site. We also acknowledge ECOGI for giving access to geophysical logs from the Rittershoffen site. Helpful comments by the H2020 MEET consortium are gratefully acknowledged. We thank three anonymous reviewers and the editorial board who helped improve this manuscript. M.S.N. Carpenter post-edited the English style and grammar.

Conflicts of Interest: The authors declare no conflict of interest.

\section{References}

1. Moeck, I.S. Catalog of geothermal play types based on geologic controls. Renew. Sust. Energ. Rev. 2014, 37, 867-882. [CrossRef]

2. Olasolo, P.; Juárez, M.C.; Morales, M.P.; Liarte, I.A. Enhanced geothermal systems (EGS): A review. Renew. Sust. Energ. Rev. 2016, 56, 133-144. [CrossRef]

3. Levi, H. Die Produktionsgeschichte der Erdöllagerstätte von Pechelbronn unter besonderer Berücksichtigung ihres bergmännischen Abbaus. Erdöl Kohle Erdgas Petrochem 1962, 15, 169-176.

4. Sittler, C. Les Hydrocarbures d'Alsace dans le context historique et géodynamique du fossé Rhénan [The case history of oil occurrence in the Rhine Rift Valley]. Bull. Centres Rech. Explor.Prod. Elf-Aquitaine 1985, 9, 335-371.

5. Genter, A.; Traineau, H. Borehole EPS-1, Alsace, France: Preliminary geological results from granite core analyses for hot dry rock research. Sci. Drill. 1992, 3, 205-214.

6. Ledésert, B.; Dubois, J.; Genter, A.; Meunier, A. Fractal analysis of fractures applied to Soultz-sous-Forêts Hot Dry Rock geothermal program. J. Volcanol. Geotherm. Res. 1993, 57, 1-17. [CrossRef]

7. Dezayes, C.; Genter, A.; Valley, B. Structure of the low permeable naturally fractured geothermal reservoir at Soultz. C. R. Geosci. 2010, 342, 517-530. [CrossRef]

8. Sausse, J.; Dezayes, C.; Dorbath, L.; Genter, A.; Place, J. 3D model of fracture zones at Soultz-sous-Forêts based on geological data, image logs, induced microseismicity and vertical seismic profiles. C. R. Geosci. 2010, 342, 531-545. [CrossRef]

9. Vidal, J.; Genter, A.; Schmittbuhl, J. Pre- and post-stimulation characterization of geothermal well GRT-1, Rittershoffen, France: Insights from acoustic image logs of hard fractured rock. Geophys. J. Int. 2016, 206, 845-860. [CrossRef]

10. Baujard, C.; Genter, A.; Dalmais, E.; Maurer, V.; Hehn, R.; Rosillette, R.; Vidal, J.; Schmittbuhl, J. Hydrothermal characterization of wells GRT-1 and GRT-2 inRittershoffen, France: Implications on the understanding of naturalflow systems in the rhine graben. Geothermics 2017, 65, 255-268. [CrossRef] 
11. Komninou, A.; Yardley, B.W.D. Fluid-rock interactions in the Rhine Graben: A thermodynamic model of the hydrothermal alteration observed in deep drilling. Geochim. Cosmochim. Acta 1997, 61, 515-531. [CrossRef]

12. Sanjuan, B.; Millot, R.; Innocent, C.; Dezayes, C.; Scheiber, J.; Brach, M. Major geochemical characteristics of geothermal brines from the Upper Rhine Graben granitic basement with constraints on temperature and circulation. Chem. Geol. 2016, 428, 27-47. [CrossRef]

13. Pauwels, H.; Fouillac, C.; Fouillac, A.-M. Chemistry and isotopes of deep geothermal saline fluids in the Upper Rhine Graben: Origin of compounds and water-rock interactions. Geochim. Cosmochim. Acta 1993, 57, 2737-2749. [CrossRef]

14. Aquilina, L.; Pauwels, H.; Genter, A.; Fouillac, C. Water-rock interaction processes in the Triassic sandstone and the granitic basement of the Rhine Graben: Geochemical investigation of a geothermal reservoir. Geochim. Cosmochim. Acta 1997, 61, 4281-4295. [CrossRef]

15. Aquilina, L.; Genter, A.; Elsass, P.; Pribnow, D. Evolution of Fluid Circulation in the Rhine Graben: Constraints from the Chemistry of the Present Fluids. In Hydrogeology of Crystalline Rocks; Stober, I., Bucher, K., Eds.; Chapter 4; Kluwer Academic Publishers: Dordrecht, Germany, 2000; pp. 177-203.

16. Gérard, A.; Kappelmeyer, O. The Soultz-sous-Forêts project. Geothermics 1987, 16, 393-399. [CrossRef]

17. Vidal, J.; Genter, A. Overview of naturally permeable fractured reservoirs in the central and southern Upper Rhine Graben: Insights from geothermal wells. Geothermics 2018, 74, 57-73. [CrossRef]

18. Agemar, T.; Schellschmidt, R.; Schulz, R. Subsurface temperature distribution in Germany. Geothermics 2012, 44, 65-77. [CrossRef]

19. Vernoux, J.F.; Lambert, M. Aquifères profonds d'Alsace. Constitution d'une base de données à usage géothermique. In Report BRGM/IMRG SGN/IRG ARG 93 T37; Bureau de Recherches Géologiques et Minières: Orléans, France, 1993; p. 41.

20. Ledésert, B.; Joffre, J.; Amblès, A.; Sardini, P.; Genter, A.; Meunier, A. Organic matter in the Soultz HDR granitic thermal exchanger (France): Natural tracer of fluid circulations between the basement and its sedimentary cover. J. Volcanol. Geotherm. Res. 1996, 70, 235-253. [CrossRef]

21. Sittler, C. Le pétrole dans le departement du Haut-Rhin. Bilan d'un siècle et demi de recherches et d'exploitation. Sci. Géol. Bull. 1972, 25, 151-161. [CrossRef]

22. Clauser, C.; Villinger, H. Analysis of conductive and convective heat transfer in a sedimentary basin, demonstrated for the Rheingraben. Geophys. J. Int. 1990, 100, 393-414. [CrossRef]

23. Freymark, J.; Bott, J.; Cacace, M.; Ziegler, M.; Scheck-Wenderoth, M. Influence of the Main Border Faults on the 3D Hydraulic Field of the Central Upper Rhine Graben. Geofluids 2019, 2019, 21. [CrossRef]

24. Böcker, J.; Littke, R. Thermal maturity and petroleum kitchen areas of Liassic Black Shales (Lower Jurassic) in the central Upper Rhine Graben, Germany. Int. J. Earth. Sci. (Geol. Rundsch.) 2016, 105, 611-636. [CrossRef]

25. Böcker, J.; Littke, R.; Forster, A. An overview on source rocks and the petroleum system of the central Upper Rhine Graben. Int. J. Earth. Sci. (Geol. Rundsch.) 2017, 106, 707-742. [CrossRef]

26. Hillebrand, T.; Leythaeuser, D. Reservoir geochemistry of the Stockstadt oilfield. Org. Geochem. 1992, 19, 119-131.

27. Ziegler, P.A. Geological Atlas of Western and Central Europe, 2nd ed.; Shell International Petroleum Mij BV: London, UK, 1990.

28. Eisbacher, G.H.; Fielitz, W. Karlsruhe und seine Region. In Nordschwarzwald, Kraichgau, Neckartal, Südlicher Odenwald, Oberrhein-Graben, Pfälzerwald und Westliche Schwäbische Alb; Borntraeger Science Publishers: Stuttgart, Germany, 2010.

29. Schumacher, M.E. Upper Rhine Graben: Role of preexisting structures during rift evolution. Tectonics 2002, 6,1-17. [CrossRef]

30. Dèzes, P.; Schmid, S.M.; Ziegler, P.A. Evolution of the European Cenozoic Rift System: Interaction of the Alpine and Pyrenean orogens with their foreland lithosphere. Tectonophysics 2004, 389, 1-33. [CrossRef]

31. Grimm, K.I. Stratigraphie von Deutschland IX-Tertiär. In Teil 1: Oberrheingraben und Benachbarte Tertiärgebiete; Schweizerbart: Stuttgart, Germany, 2011.

32. Villemin, T.; Bergerat, F. L'évolution structurale du Fosse rhénan au cours du Cénozoïque: Un bilan de la déformation et des effets thermiques de l'extension. Bull. Soc. geol. Fr. 1987, 8, 245-255. [CrossRef]

33. Ledésert, B.; Hébert, R.; Grall, C.; Genter, A.; Dezayes, C.; Bartier, D.; Gérard, A. Calcimetry as a useful tool for a better knowledge of flow pathways in the Soultz-sous-Forêts Enhanced Geothermal System. J. Volcanol. Geotherm. Res. 2009, 181, 106-114. [CrossRef] 
34. Hettkamp, T.; Baumgartner, J.; Baria, R.; Gérard, A.; Gandy, T.; Michelet, S.; Teza, D. Electricity production from Hot Rocks. In Proceedings of the 29thWorkshop on Geothermal Reservoir Engineering, Stanford, CA, USA, 26-28 January 2004; pp. 184-193.

35. Genter, A.; Homeier, G.; Chèvremont, P.; Tenzer, H. Deepening of GPK-2 HDR borehole, 3880-5090 m (Soultz-sous-Forêts, France)- Geological Monitoring. In Report BRGM R 40685; Bureau de Recherches Géologiques et Minières: Orléans, France, 1999; p. 44. Available online: http://infoterre.brgm.fr/rapports/RR40685-FR.pdf (accessed on 12 November 2020).

36. Genter, A.; Tenzer, H. Geological monitoring of GPK-2 HDR borehole, 1420-3880 m (Soultz-sous-Forêts, France). Soultz-sous-Forêts. In Report BRGM/RR-38629; Bureau de Recherches Géologiques et Minières: Orléans, France, 1995; p. 46. Available online: http://infoterre.brgm.fr/rapports/RR-38629-FR.pdf (accessed on 12 November 2020).

37. Dezayes, C.; Genter, A.; Homeier, G.; Degouy, M.; Stein, G. Geological Study of GPK3 HFR Borehole (Soutlz-sous-Forêts, France). In BRGM/RP-52311-FR; Bureau de Recherches Géologiques et Minières: Orléans, France, 2003; p. 128. Available online: http://infoterre.brgm.fr/rapports/RP-52311-FR.pdf (accessed on 12 November 2020).

38. Dezayes, C.; Genter, A.; Gentier, S. Fracture Network of the EGS Geothermal Reservoir at Soultz-sous-Forêts (Rhine Graben, France). GRC 2004, 11, 2004.

39. Meller, C.; Ledésert, B. Is there a link between mineralogy, petrophysics, and the hydraulic and seismic behavior of the Soultz-sous-Forêts granite during stimulation? A review and re-interpretation of petro-hydromechanical data towards a better understanding of induced seismicity and fluid flow. J. Geophys. Res. Solid Earth 2017, 122, 9755-9774. [CrossRef]

40. Velde, B. Electron microprobe analysis of clay minerals. Clay Miner. 1984, 19, 243-247. [CrossRef]

41. Liewig, N.; Clauer, N. K-Ar dating of varied microtextural illite in Permian gas reservoirs, northern Germany. Clay Miner. 2000, 35, 271-281. [CrossRef]

42. Clauer, N.; Liewig, N.; Ledésert, B.; Zwingmann, H. Evolution of Triassic sandstones from Vosges mountains-Rhine graben structural setting, NE France, based on K-Ar illite dating: Local and regional geodynamic implications. Clay Miner. 2008, 43, 363-379. [CrossRef]

43. Glasmacher, U.A.; Tschernoster, R.; Clauer, N.; Spaeth, G. K-Ar dating of magmatic sericite crystallites for determination of cooling paths of metamorphic overprints. Chem. Geol. 2001, 175, 673-687. [CrossRef]

44. Honty, M.; Uhlik, P.; Sucha, V.; Caplovicova, M.; Francu, J.; Clauer, N.; Biron, A. Smectite to illite alteration in salt-bearing bentonites; the East Slovak Basin. Clays Clay Miner. 2004, 52, 533-551. [CrossRef]

45. Bonhomme, M.G.; Thuizat, R.; Pinault, Y.; Clauer, N.; Wendling, A.; Winkler, R. Méthode de datation potassium/argon. Appareillage et technique. In Note Technique de l'Institut de Géologie de Strasbourg; Institut de Géologie de Strasbourg: Strasbourg, France, 1975; p. 53.

46. Bartier, D.; Ledésert, B.; Clauer, N.; Meunier, A.; Liewig, N.; Morvan, G.; Addad, A. Hydrothermal alteration of the Soultz-sous-Forêts granite (Hot Fractured Rock geothermal exchanger) into a tosudite and illite assemblage. Eur. J. Mineral. 2008, 20, 131-142. [CrossRef]

47. Ledésert, B.; Berger, G.; Meunier, A.; Genter, A.; Bouchet, A. Diagenetic-type reactions related to hydrothermal alteration in the Soultz-sous-Forêts granite. Eur. J. Mineral. 1999, 11, 731-741. [CrossRef]

48. Poty, B.; Leroy, J.; Jachimovicz, L. Un nouvel appareil pour la mesure des températures sous microscope: L'installation thermométrique Chaixmeca. Bull. Soc. Fr. Minéral. Cristallogr. 1976, 99, 182-186. [CrossRef]

49. White, A.F.; Schulz, M.S.; Lowenstern, J.B.; Vivit, D.V.; Bullen, T.D. The ubiquitous nature of accessory calcite in granitoid rocks: Implications for weathering, solute evolution, and petrogenesis. Geochim. Cosmochim. Acta 2005, 69, 1455-1471. [CrossRef]

50. Nédélec, A.; Trindade, R.; Peschler, A.; Archanjo, C.; Macouin, M.; Poitrasson, F.; Bouchez, J.-L. Hydrothermally-induced changes in mineralogy and magnetic properties of oxidized A-type granites. Lithos 2015, 212-215, 145-157. [CrossRef]

51. Lapointe, P.; Morris, W.A.; Harding, K.L. Interpretation of magnetic susceptibility: A new approach to geophysical evaluation of the degree of rock alteration. Can. J. Earth Sci. 1986, 23, 393-401. [CrossRef]

52. Harding, K.L.; Morris, W.A.; Balch, S.J.; Lapointe, P.; Latham, A.G. A comparison of magnetic character and alteration in three granite drill cores from eastern Canada. Can. J. Earth Sci. 1988, 25, 1141-1150. [CrossRef] 
53. Just, J.; Kontny, A.; De Wall, H.; Hirt, A.M.; Martín-Hernández, F. Development of magnetic fabrics during hydrothermal alteration in the Soultz-sous-Forêts granite from the EPS-1 borehole, Upper Rhine graben. Geol. Soc. Spec. Publ. 2004, 238, 500-526. [CrossRef]

54. Genter, A.; Traineau, H. Analysis of macroscopic fractures in granite in the HDR geothermal well EPS-1, Soultz-sous-Forêts, France. J. Volc. Geotherm. Res. 1996, 72, 121-141. [CrossRef]

55. Genter, A.; Traineau, H.; Ledésert, B.; Bourgine, B.; Gentier, S. Over 10 years of geological investigations within the HDR Soultz project, France. In Proceedings of the World Geothermal Congress 2000, Tohoku, Japan, 28 May-10 June 2000; pp. 3707-3712.

56. Sanjuan, B.; Millot, R.; Dezayes, C.; Brach, M. Main characteristics of the deep geothermal brine $(5 \mathrm{~km})$ at Soultz-sous-Forêts (France) determined using geochemical and tracer test data. C. R. Geosci. 2010, 342, 546-559. [CrossRef]

57. Sanjuan, B.; Millot, R.; Ásmundsson, R.; Brach, M.; Giroud, N. Use of two new Na/Li geothermometric relationships for geothermal fluids in volcanic environments. Chem. Geol. 2014, 389, 60-81. [CrossRef]

58. Genter, A.; Traineau, H.; Dezayes, C.; Elsass, P.; Ledésert, B.; Meunier, A.; Villemin, T. Fracture analysis and reservoir characterization of the granitic basement in the HDR Soultz project. Geotherm. Sci. Technol. 1995, 4, 189-214.

59. Sardini, P.; Ledésert, B.; Touchard, G. Quantification of microscopic porous networks by image analysis and measurements of permeability in the Soultz-sous-Forêts granite (Alsace, France). In Fluid Flow and Transport in Rocks-Mechanisms and Effects; chapter 10, 171-188; Jamtveit, B., Yardley, B., Eds.; Chapman \&Hall: London, UK; Weinheim, Germany; New York, NY, USA; Tokyo, Japan; Melbourne, Australia; Madras, India, 1997; p. 319.

60. Hébert, R.L.; Ledésert, B.; Bartier, D.; Dezayes, C.; Genter, A.; Grall, C. The Enhanced Geothermal System of Soultz-sous-Forêts: A study of the relationships between fracture zones and calcite content. J. Volcanol. Geotherm. Res. 2010, 196, 126-133. [CrossRef]

61. Ledésert, B.; Hébert, R.; Genter, A.; Bartier, D.; Clauer, N.; Grall, C. Fractures, Hydrothermal alterations and permeability in the Soultz Enhanced Geothermal System. C. R. Geosci. 2010, 342, 607-615, special volume. [CrossRef]

62. Freymark, J.; Sippel, J.; Scheck-Wenderoth, M.; Bar, K.; Stiller, M.; Fritsche, J.-G.; Kracht, M. The deep thermal field of the Upper Rhine Graben. Tectonophysics 2017, 694, 114-129. [CrossRef]

63. Bächler, D.; Kohl, T.; Rybach, L. Impact of graben-parallel faults on hydrothermal convection-Rhine Graben case study. Phys. Chem. Earth 2003, 28, 431-441. [CrossRef]

64. Baillieux, P.; Schill, E.; Edel, J.-B.; Mauri, G. Localization of temperature anomalies in the Upper Rhine Graben: Insights from geophysics and neotectonic activity. Int. Geol. Rev. 2013, 55, 1744-1762. [CrossRef]

65. Baillieux, P.; Schill, E.; Abdelfettah, Y.; Dezayes, C. Possible natural fluid pathways from gravity pseudo-tomography in the geothermal fields of Northern Alsace (Upper Rhine Graben). Geotherm. Energy 2014, 2, 1-14. [CrossRef]

66. Rummel, F.; Haack, U.; Gohn, E. Uranium, Thorium and Potassium Content and Derived Heat Production Rate (Yellow Report No. 6-9); Ruhr Universität: Bochum, Germany, 1988.

67. Grecksch, G.; Ortiz, A.; Schellschmidt, R. Thermophysical Study of GPK2 and GPK3 Granite Samples: HDR Project Soultz Report; GGA-Bericht: Hannover, Germany, 2003.

68. Pribnow, D. The Deep Thermal Regime in Soultz and Implications for Fluid Flow: HDR Project Soultz Report; GGA-Bericht: Hannover, Germany, 2000.

69. Pribnow, D.; Clauser, C. Heat and fluid flow at the Soultz Hot Dry Rock system in the Rhine Graben. In Proceedings of the World Geothermal Congress, Kyushu-Tohoku, Japan, 28 May-10 June 2000.

70. Pribnow, D.; Schellschmidt, R. Thermal tracking of upper crustal fluid flow in the Rhine Graben. Geophys. Res. Lett. 2000, 27, 1957-1960. [CrossRef]

71. Bao, T.; Liu, Z.L. Thermohaline stratification modeling in mine water via double-diffusive convection for geothermal energy recovery from flooded mines. Appl. Energy. 2019, 237, 566-580. [CrossRef]

72. Genter, A.; Evans, K.; Cuenot, N.; Fritsch, D.; Sanjuan, B. Contribution of the exploration of deep crystalline fractured reservoir of Soultz to the knowledgeof Enhanced Geothermal Systems (EGS). C.R. Geosci. 2010, 342, 502-516. [CrossRef] 
73. Dubois, M.; Ledésert, B.; Potdevin, J.L.; Vançon, S. Détermination des conditions de précipitation des carbonates dans une zone d'altération du granite de Soultz (soubassement du fossé rhénan, France): L'enregistrement des inclusions fluides. C. R. Acad. Sci. 2000, 331, 303-309. [CrossRef]

74. Dubois, M.; Ayt Ougougdal, M.; Meere, P.; Royer, J.J.; Boiron, M.C.; Cathelineau, M. Temperature of palaeo- to modern self sealing within a continental rift basin: The fluid inclusion data (Soultz-sous-Forêts, Rhine graben, France). Eur. J. Mineral. 1996, 8, 1065-1080. [CrossRef]

75. Smith, M.P.; Savary, V.; Yardley, B.W.D.; Valley, J.W.; Royer, J.J.; Dubois, M. The evolution of the deep flow regime at Soultz-sous-Forêts, Rhine Graben, eastern France: Evidence from a composite quartz vein. J. Geophys. Res. 1998, 103, 27223-27237. [CrossRef]

76. Ngo, V.V.; Lucas, Y.; Clément, A.; Fritz, B. Modeling the impact of temperature on the saturation state and behavior of minerals in the Soultz-sous-Forêts geothermal system. Geothermics 2016, 64, 196-208. [CrossRef]

77. Espitalié, J.; Marquis, F.; Barsony, I.; Fritz, B. Diagraphie géochimique du forage géothermique de Soultz-sous-Forêts (GPKI) en Alsace. IFP Doc. 1988, 35829, 6.

78. Vallier, B.; Magnenet, V.; Schmittbuhl, J.; Fond, C. THM modeling of gravity anomalies related to deep hydrothermal circulation at Soultz-sous-Forêts (France). Geotherm. Energy 2020, 8, 13. [CrossRef]

79. Aquilina, L.; de Dreuzy, J.-R.; Bour, O.; Davy, P. Porosity and fluid velocities in the upper continental crust ( 2 to $4 \mathrm{~km}$ ) inferred from injection tests at the Soultz-sous-Forêts geothermal site. Geochim. Cosmochim. Acta 2004, 68, 2405-2415. [CrossRef]

80. Hébert, R.; Ledésert, B. Calcimetry at Soultz-sous-Forêts Enhanced Geothermal System: Relationships with fracture zones, flow pathways and reservoir chemical stimulation results. In Geothermal Energy, Technology and Geology; Chapter 3; Yang, J., Ed.; Nova Science Publishers Inc.: Huntington, NY, USA, 2012; pp. 93-113.

81. Surma, F.; Géraud, Y. Porosity and Thermal Conductivity of the Soultz-sous-Forêts Granite. Pure Appl. Geophys. 2003, 160, 1125-1136. [CrossRef]

82. Gueguen, Y.; Palciauskas, V. Introduction à la Physique des Roches; Hermann: Paris, France, 1997; 312p.

83. Bao, T.; Meldrum, J.; Green, C.; Vitton, S.; Liu, Z.; Bird, K. Geothermal energy recovery from deep flooded copper mines for heating. Energy Conv. Manag. 2019, 183, 604-616. [CrossRef]

84. Meller, C.; Kohl, T. The significance of hydrothermal alteration zones for the mechanical behavior of a geothermal reservoir, Geothermal Energy. Geotherm. Energy 2014, 2, 12. [CrossRef]

Publisher's Note: MDPI stays neutral with regard to jurisdictional claims in published maps and institutional affiliations.

(C) 2020 by the authors. Licensee MDPI, Basel, Switzerland. This article is an open access article distributed under the terms and conditions of the Creative Commons Attribution (CC BY) license (http://creativecommons.org/licenses/by/4.0/). 